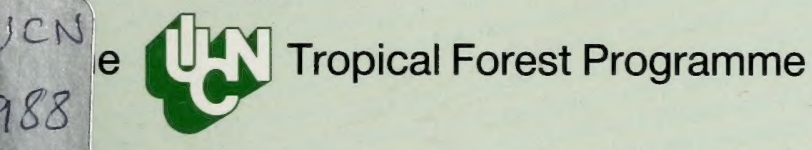

\section{Rare Tropical}

Timbers

SARA OLDFIELD

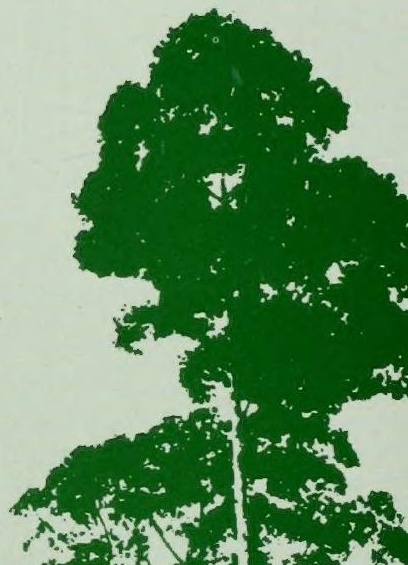

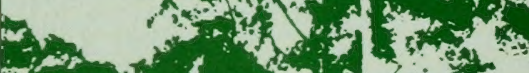

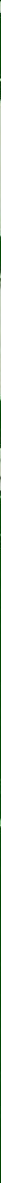


A/N 41: :IUCN. 1988 
RARE TROPICAL TIMBERS 


\section{IUCN}

IUCN (International Union for Conservation of Nature and Natural Resources) is a membership organisation comprising governments, non-governmental organisations (NGOs), research institutions, and conservation agencies, whose objective is to promote and encourage the protection and sustainable use of living resources.

Founded in 1948, IUCN has nearly 600 members representing 116 countries. Its six Commissions comprise a global network of experts on threatened species, protected areas, ecology, environmental planning, environmental law, and environmental education. Its thematic programmes include tropical forests, wetlands, marine ecosystems, plants, oceanic islands, the Sahel, Antarctica, and population and sustainable development.

\section{THE IUCN TROPICAL FOREST PROGRAMME}

The IUCN Tropical Forest Programme coordinates and reinforces activities of the IUCN members and Secretariat which deal with tropical moist forests. The Programme focuses on the conservation of species and ecological processes, and on investigating and promoting sustainable use of the resources of these forests.

The Programme includes international and national policy initiatives and strategies as well as field projects addressing selected problems in managing the World's most biologically significant tropical forests. These selected projects put the World Conservation Strategy into action by reconciling the requirements of conservation with national development and the needs of people living in forest areas. Special emphasis is given to the development of compatible uses for buffer zones around national parks and reserves.

IUCN develops its positions and policies on the basis of the concerns and information communicated by members, trends identified by monitoring activities, and the feedback from numerous field projects. Data on species of plants and animals, and on tropical forest sites which are important for biological and ecosystem conservation, are held by the IUCN Conservation Monitoring Centre in Cambridge, UK.

This series of publications from the Tropical Forest Programme, in conjunction with regular meetings, enables IUCN to communicate policies and technical guidance to governments, major international institutions, development planners, and conservation professionals. The Programme works closely with development assistance agencies, governments and NGOs to ensure that conservation priorities are adequately addressed in their activities.

The Tropical Forest Programme receives generous financial support from the Government of Sweden. It is coordinated by Jeffrey Sayer at IUCN Headquarters in Gland, Switzerland. Mark Collins is responsible for tropical forest monitoring at the IUCN Conservation Monitoring Centre. 
The IUCN Tropical Forest Programme

\section{RARE TROPICAL TIMBERS}

by

\section{Sara Oldfield}

Conservation Consultant

The IUCN Tropical Forest Programme

International Union for Conservation of Nature and Natural Resources 
Published by IUCN, Gland, Switzerland and Cambridge, UK. $\begin{array}{ll}\text { Copyright: } & 1988 \text { International Union for Conservation of Nature and Natural } \\ \text { Resources }\end{array}$

Reproduction of this publication for educational or other non-commercial purposes is authorised without prior permission from the copyright holder.

Reproduction for resale or other commercial purposes is prohibited without the prior written permission of the copyright holder.

Citation:

Oldfield, Sara (1988). Rare Tropical Timbers. IUCN, Gland, Switzerland and Cambridge, UK. 48 pp., 8 photos, tables.

ISBN: $\quad 2-88032-959-0$

Printed by: $\quad$ Parchment (Oxford) Limited, UK

Typeset by: IUCN Publications Services Unit

Cover design by: James Butler

Cover photo: Measuring logs in Sabah. WWF/Sylvia Yorath

Available from: IUCN Publications Services,

219c Huntingdon Road, Cambridge CB3 ODL, UK; or

Avenue du Mont-Blanc, CH-1196 Gland, Switzerland

The designations of geographical entities in this book, and the presentation of the material, do not imply the expression of any opinion whatsoever on the part of IUCN concerning the legal status of any country, territory, or area, or of its authorities, or concerning the delimitation of its frontiers or boundaries.

The views of the author expressed in this publication do not necessarily reflect those of IUCN. 


\section{TABLE OF CONTENTS}

Page

List of tables

Abbreviations used in the text

Acknowledgements

vi

vii

viii

Introduction

International Trade in Tropical Timber - A Conservation Problem?

Lesser-known timber species

Tropical timber species threatened by trade

Conservation Measures for Tropical Timber Species

Conservation trade controls

The Convention on International Trade in Endangered Species of Wild Fauna and Flora (CITES)

The conservation role of the International Tropical Timber Organisation (ITTO)

Data on the International Tropical Timber Trade

Current sources of data

FAO

International Trade Centre UNCTAD/GATT (ITC)

Examples of regional timber data bases

Other sources of data

The Need for Further Tropical Timber Data for Conservation Programmes

Meeting conservation data needs

Annexe

Threatened taxa of selected families with IUCN conservation categories 


\section{LIST OF TABLES}

Page

1. Wood production and export for selected countries 3

2. Over-exploited commercial tropical timbers included in the FAO 9 Databook on Endangered Tree and Shrub Species and Provenances

3. Tropical timber species included in the IUCN Plant Red Data Book 10

4. Tropical timber species included in the Appendices of CITES 12

5. Luxury tropical timbers in the Leguminosae: species of conservation 13 concern

6. Log exports banned by Ghana 16

7. Principal commercial tropical hardwoods used in saw and veneer log 22 production 


\section{ABBREVIATIONS USED IN THE TEXT}

$\begin{array}{ll}\text { ASEAN } & \text { Association of South East Asian Nations } \\ \text { ATIBT } & \text { Association Technique Internationale des Bois Tropicaux } \\ \text { ATO } & \text { African Timber Organisation } \\ \text { CCCN } & \text { Customs Co-operation Council Nomenclature } \\ \text { CINTRAFOR } & \begin{array}{l}\text { Center for International Trade in Forest Products } \\ \text { Convention on International Trade in Endangered Species of Wild } \\ \text { CITES }\end{array} \\ \begin{array}{l}\text { Fauna and Flora } \\ \text { CMC }\end{array} & \text { Conservation Monitoring Centre } \\ \text { CTFT } & \text { Centre Technique Forestier Tropical } \\ \text { ECE } & \text { Economic Commission for Europe } \\ \text { ECG } & \text { Ecosystems Conservation Group } \\ \text { EPDU } & \text { Electronic Data Processing Unit (ITC) } \\ \text { FAO } & \text { Food and Agriculture Organisation of the United Nations } \\ \text { IFLA } & \text { Instituto Forestal Latinamericano } \\ \text { INPA } & \text { Instituto Nacional de Pesquisas da Amazonia } \\ \text { ITTA } & \text { International Tropical Timber Agreement } \\ \text { ITTO } & \text { International Tropical Timber Organisation } \\ \text { ITC } & \text { International Trade Centre } \\ \text { ITE } & \text { Institute of Terrestrial Ecology } \\ \text { IUCN } & \text { International Union for Conservation of Nature and Natural Resources } \\ \text { NAS } & \text { National Academy of Sciences } \\ \text { OTEC } & \text { Organisation of Timber Exporting Countries (proposed) } \\ \text { RIFALC } & \text { Latin American and Caribbean Forest Information Network } \\ \text { SEALPA } & \text { Southeast Asian Lumber Producers Association } \\ \text { SITC } & \text { Standard International Trade Classification } \\ \text { UNCTAD } & \text { United Nations Conference on Trade and Development } \\ \text { UNEP } & \text { United Nations Environment Programme } \\ \text { UNSO } & \text { United Nations Statistical Office } \\ \text { Unesco } & \text { United Nations Educational, Scientific and Cultural Organisation } \\ \text { WRI } & \text { World Resources Institute } \\ \text { WTMU } & \text { Wildlife Trade Monitoring Unit } \\ \end{array}$




\section{ACKNOWLEDGEMENTS}

This paper is based on a feasibility study carried out for the Wildlife Trade Monitoring Unit (WTMU), a unit of IUCN's Conservation Monitoring Centre, on the monitoring of rare tropical timber species in international trade. The feasibility study was funded by the Commission of the European Communities.

Thanks are due to Jon Barzdo and the staff of WTMU for encouragement and assistance in carrying out the feasibility study and to the FAO Forestry Department and UNCTAD International Trade Centre for generously providing information for the report. 


\section{INTRODUCTION}

Destruction of tropical rain forests is the most urgent international conservation problem representing the greatest potential loss of species. Rain forests probably harbour over half the world's species of plants and animals. Included among these are plants which yield valuable timbers, rattans, spices, nuts, fruits, medicines and a wealth of other economically important products. Complex and inter-relating factors are bringing about the loss of rain forest and the species which they contain. Commercial logging for timber is one factor in the clearance and disruption of forest ecosystems, the timber extracted being either for local consumption or international trade. Virtually all the tropical timber entering the world market is from natural forests, harvested on an unsustainable basis, and there is therefore a very real possibility of the economic potential of forests being destroyed through the over-exploitation of timber species.

The effect of logging on individual species of timber trees has received surprisingly little attention and information on the conservation status of valuable tropical timbers is difficult to come by. This lack of species-specific data represents a major area of weakness in planning for the rational utilisation and conservation of tropical forests. The need for such data is becoming increasingly urgent with the ever-increasing world demand for timber and wood products, calls for trade bans, the depletion of traditionally valued tropical hardwoods and the promotion of a wider range of "lesser-known species". This paper reviews the existing information on threatened tropical timber species and the sources of data on tropical timber species in trade. It attempts to relate the two sets of data and considers the implications for conservation.

Trees extracted from tropical forests for the international market are either selected on a species basis to meet specific demands or felled to supply general and non-specific wood products. Tropical hardwoods are required by importing countries as a substitute for traditionally used (and in some cases over-exploited) high-value temperate timbers such as oak and walnut. In addition certain tropical timbers have specific technical and decorative properties which temperate species lack. These are the timber species which have already been severely depleted in tropical forests and remain vulnerable to over-exploitation. Wood is also imported from tropical countries to meet more general timber needs, for example in the construction industry, where prices compare favourably with those of temperate supplies. Non-specific wood products such as pulpwood and chipboard are also produced by tropical countries for the export market. These are products of from clear-felling which does not put commercial pressure on individual timber species but may nevertheless threaten locally restricted tropical tree species with restricted distributions.

Timber and wood products are major international trade commodities and represent an important source of export income to the less developed countries where the tropical forest resource is concentrated. Data on trade in tropical timber are collected both nationally and internationally for economic analysis and forecasting. The two principal international organisations which collect and publish information on tropical timber trade are the Timber Resources Division of the Food and Agriculture Organisation of the United Nations (FAO), and the UNCTAD International Trade Centre (ITC).

The collection of trade data has implications for the management and conservation of tropical timber stocks in the wild. This aspect of monitoring has scarcely been considered in relation to international conservation programmes.

The International Tropical Timber Agreement (ITTA), which came into force on 1 April 1985, aims to improve monitoring of the tropical timber trade and also to encourage the conservation of tropical forest resources. ITTA should become an important force in tropical forest conservation bringing together environmental and trade interests. The agreement may provide an international framework for monitoring trade in rare timbers. It is important at this stage to sustain the conservation momentum of the Agreement and in order to do so accurate factual information is needed to support conservation initiatives. 


\section{Rare Tropical Timbers}

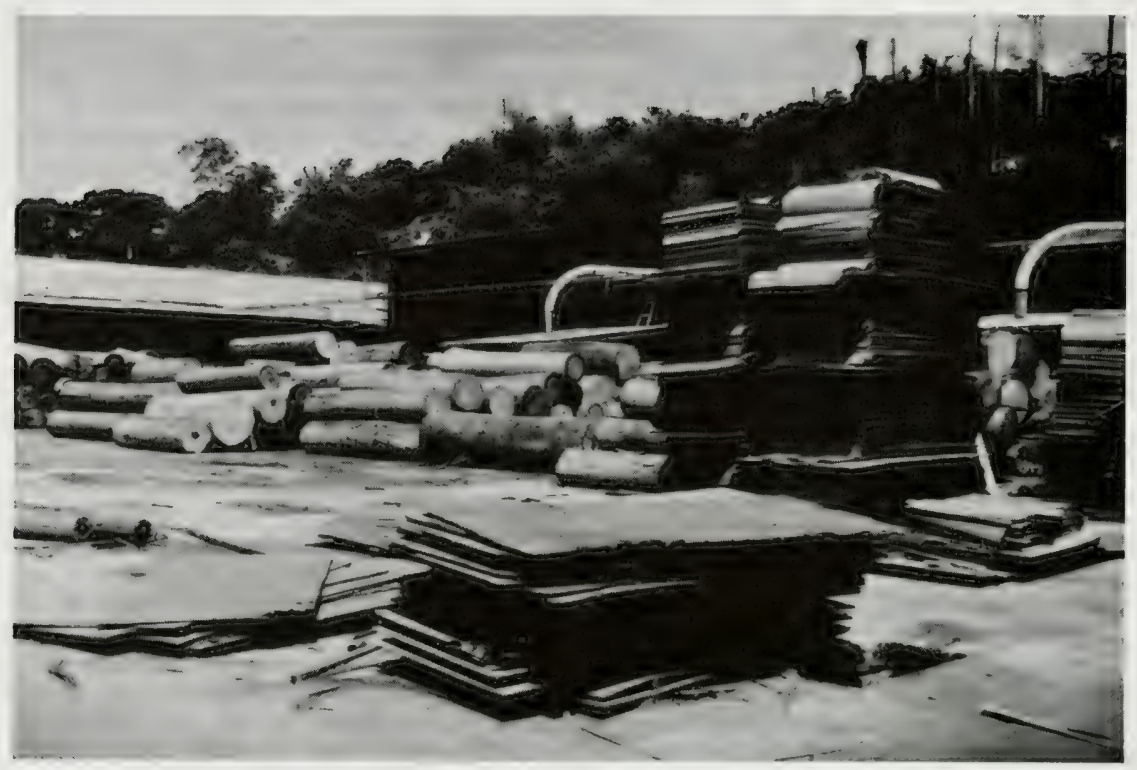

Logs and plywood at a Malaysian plywood factory. Photo: WWF/Sylvia Yorath 


\section{INTERNATIONAL TRADE IN TROPICAL TIMBER A CONSERVATION PROBLEM?}

Deforestation in the tropics is a complex issue in which the commercial extraction of timber plays a relatively small but significant part. The role of logging in forest disruption and ultimate destruction has been discussed by various authors and the emphasis placed on commercial timber extraction in forest loss varies widely according to the point of view of the author. The importance of international timber trade as a factor in tropical deforestation is also widely debated. Clearly the situation varies from country to country. Whereas commercial timber extraction is scarcely established in some countries either for domestic use or the export trade, in others the export of wood has long formed the mainstay of the economy. Table 1 shows the relative importance of domestic wood consumption and export of timber for stlected countries.

Table 1: Wood production and export for selected countries (1984 figures)

\begin{tabular}{ccc}
\multicolumn{2}{c}{$\begin{array}{c}\text { Wood production } \\
(\mathrm{x} 1000 \mathrm{cu} \mathrm{m})\end{array}$} & $\begin{array}{c}\text { Exports } \\
(\mathrm{x} 1000 \mathrm{cu} \mathrm{m})\end{array}$ \\
Industrial $\quad \begin{array}{c}\text { Fuelwood and } \\
\text { charcoal }\end{array}$ & Total &
\end{tabular}

$\begin{array}{lrrrr}\text { Brazil } & 57,670 & 164,507 & 222,177 & 30 \\ \text { Burma } & 3,064 & 16,433 & 19,497 & 100 \\ \text { Chile } & 8,979 & 5,992 & 14,971 & 906 \\ \text { Colombia } & 2,673 & 14,243 & 16,916 & 0 \\ \text { Gabon } & 1,484 & 1,222 & 2,076 & 1,378 \\ \text { Indonesia } & 29,135 & 119,059 & 148,194 & 2,242 \\ \text { Ivory Coast } & 4,493 & 7,697 & 12,190 & 2,156 \\ \text { Malaysia } & 32,802 & 7,410 & 40,212 & 17,245 \\ \text { Nigeria } & 7,360 & 84,682 & 92,042 & 10 \\ \text { Philippines } & 6,977 & 28,582 & 35,559 & 1,492\end{array}$

Source: Boelcke and Croze (1986)

Nearly all industrial wood from tropical sources (and certainly that traded internationally) is extracted from closed broadleaved forest (Hansom, 1985). Every year 5 million hectares of closed tropical forests are logged. Much of the modified vegetation remains as forest which could be managed for long term timber production or conservation. Permanent deforestation amounts to 11.3 million hectares per year. International trade is obviously relevant to logging practices as approximately one quarter of industrial wood extracted from tropical forest is destined for the export market. Logging in itself does not lead to total deforestation but extraction techniques are generally ecologically destructive and logging operations frequently lead to the susequent clearance of forests for other reasons. Forest clearance for subsistence agriculture, cited by FAO as the major force in tropical deforestation, is frequently made easier by access roads that logging companies build, and fail to block off once timber extraction is completed.

The effects of commercial timber extraction in tropical areas may appear relatively minor when compared with the collection of wood for local fuel use. More than 80 per cent of the wood harvested in developing countries is used as fuel wood. However the majority of wood collection for fuel is carried out in dry forest areas (or from agricultural land), whereas most of the commercial logging is conducted in moist tropical forests. Fuelwood collection is beginning to be significant in humid forests around cities such as Kinshasa, Brazzaville and Abidjan and also in East African forest relicts but this is a new and relatively minor factor in moist forest degradation. 


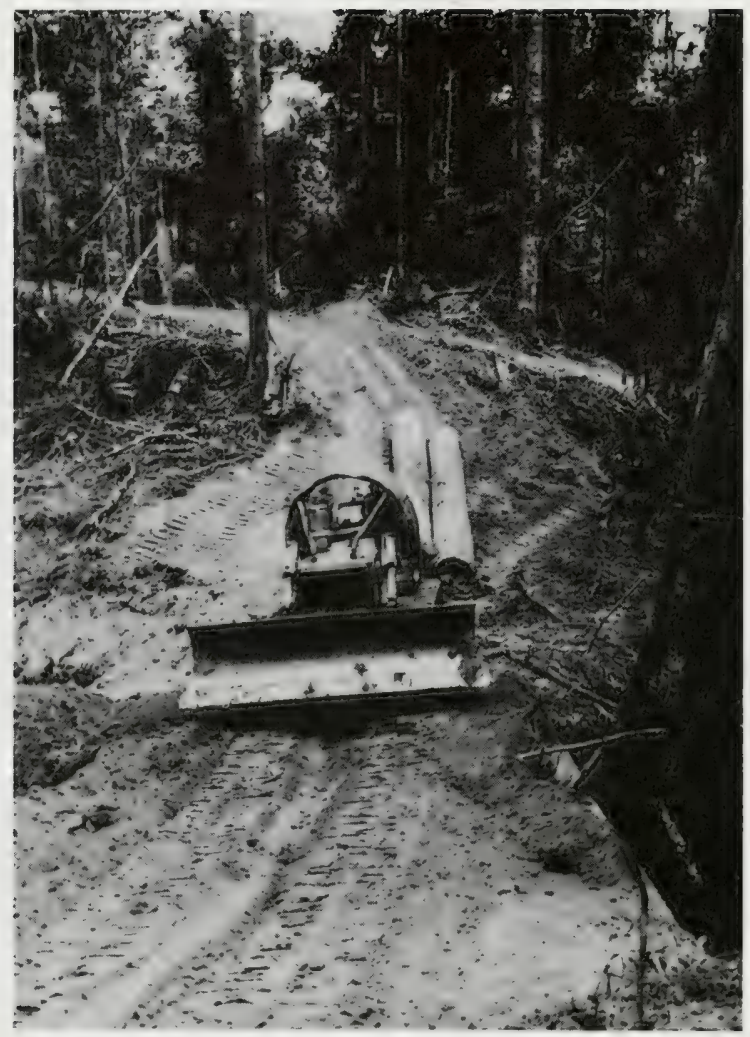

Extraction of logs from a Malaysian forest. Photo: WWF/Ken Scriven

The high proportion of wood gathered for local fuel use is frequently cited in the defence of commercial tropical timber extraction by forestry interests. The timber trade generally has been seen as adopting a defensive attitude towards its responsibilities in tropical forests by conservation groups (Nectoux, 1985).

The role of local people in forest conservation has until recently been quite overlooked. Most blame misuse of the forests on subsistence needs rather than commercial opportunism. This view has recently been now strongly challenged by more vocal and eloquent defenders of local people's needs. Shiva (1987), for example, describes how "commercialisation of the forests is the primary cause for most largescale and rapid deforestation".

There is no doubt that industrial forest resources have not been well managed in the tropics. Over the past 30 years there has been minimal investment in protecting and intensively managing forests that have been logged (WRI, 1985). A recent review of tropical rain forest management systems has shown that although, "sustainable integrated management of the tropical mixed forest is technically feasible", it has scarcely been achieved anywhere in the world because of problems concerning land-use policy, socio-economic conditions and political realities (Schmidt, in press). As a result of the lack of forest management, the virtual disappearance of commercially productive natural tropical rain forests is imminent in a number of countries, including Ivory Coast, Nigeria and Thailand. 
Commercial logging is typically quite selective (for example, extraction of $10-12 \mathrm{cu} \mathrm{m}$ of timber per hectare) and the impoverished forest left behind could retain much of its value for timber production or wildlife conservation if carefully managed. In South East Asian forests which are characterised by the presence of dominant groups of species (Dipterocarpaceae) logging has been much more intensive (extraction of $40-100 \mathrm{cu} m$ of timber per hectare). It has been suggested that "extinction as a result of logging is most unlikely except, perhaps, in very large-scale, rigorous exploitation" (Bruenig, 1985) but clearly other environmental problems will result. The physical disruption caused by intensive timber exploitation typically leads to the lack of vegetative regrowth and erosion.

The species selectively logged from natural forests are generally high value timbers which are attractive to international markets. Of Amazonia's many thousands of tree species, only about 50 are widely exploited, although as many as 400 have some commercial value (Myers, 1980). Africa exports only 35 principal species, with 10 accounting for 70 per cent of the total (Erfurth and Rusche, 1976). In South East Asia, loggers currently focus on less than 100 tree species with exports dominated by about twelve timbers (Myers, 1980). This represents a very small proportion of Asian timber diversity. Indonesia alone has around 4000 tree species, 267 of which are considered as commercial timbers (Government of Indonesia and IIED, 1985). The dipterocarp forests of Malaysia have at least 3000 species of which 408 have been introduced to international markets at some stage (Thang, 1987).

At a national level commercial timber production may concentrate almost exclusively on one or a few species. This is the case, for example, in Gabon where okoumé Aucoumea klaineana is by far the most important timber species, contributing about 90 per cent of the total production. A conservation programme is now considered necessary for this highly valued timber which is restricted to west and central Gabon and small areas of Equatorial Guinea and Congo Brazzaville.

Repeated "creaming" of the best timber trees of a few species without forest management can lead to structurally and genetically degraded forests (Roche and Dourojeanni, 1984). The potential timber species-loss through commercial exploitation is generally accorded relatively little importance however. Hansom (1985) for example points out that, "The more accessible forests of the Amazon region have been heavily exploited for popular species, but .... the consequences are economic rather than ecological except for the possible loss of the species altogether."

The concentrated removal of valuable timbers from natural forests has led to the depletion of hardwood resources of a range of species discussed more fully in the next section. Very few commercial hardwoods have been successfully established in plantations and even teak Tectona grandis, a species which is grown in plantations, is in need of active conservation. As Hedegart (1976) points out, "In spite of centuries of heavy and usually dysgenic exploitation the natural teak forests still offer valuable gene resources, but clearing, illegal exploitation, burning and grazing continue at an increasing rate." Large-scale teak plantations are being established but in most cases these represent only a fraction of the genetic variability of the species.

A similar situation of genetic degradation of a once common timber species exists for obeche Triplochiton scleroxylon, a West African species. Obeche used to dominate timber exports from Nigeria, for example, but because of over-exploitation the Nigerian government banned its export in 1975. The species is now subject to a regional conservation and breeding programme which aims to sustain production through plantation forestry (Leakey, Last and Cossalter 1984). In the same way there is now concern about okoume in Gabon. This has been grown as a plantation timber since 1944 but only a small proportion of timber felled in natural forest is replaced by plantation development. Reforestation amounts to about 1000 ha per year.

The establishment of plantations is one potential conservation measure for traditionally over-exploited timbers. Generally, however, plantation development in the tropics has concentrated on a limited number of species. Davidson (1985) lists the plantation areas of the 32 most extensively planted timber species in the tropics. Tectona grandis is the major species 
planted and other valuable tropical hardwoods listed include Dalbergia sissoo, Swietenia macrophylla and Cedrela odorata although these cover considerably smaller areas. Further research on indigenous forest plantation trees is urgently required.

A tendency to develop monoculture plantations has led to problems of crop failure through disease and pest attack, and ecological problems of soil erosion and agrochemical pollution. The conversion of natural forest to plantations has been a direct cause of deforestation and the loss of biological resources. In contrast the establishment of plantation on degraded land offers the prospect of stablising and improving the environment whilst at the same time producing an economic return.

At present the development of tropical forest plantations is not keeping pace with logging and deforestation. Less than 600,000 ha of industrial plantations are planted each year in less-developed countries (WRI, 1985). Only about 0.5 per cent of the world's tropical woody vegetation consists of forest plantations. Natural forest continue to supply most of the timber in international trade.

\section{LESSER-KNOWN TIMBER SPECIES}

A small number of tropical hardwood species have traditionally dominated the international timber market, leading to a situation summarised by Overbeek (1982) as follows:

a) Traditional species have become scarce and expensive as a result of prolonged exploitation of the areas concerned.

b) This has led to the appearance of lesser-known species on the market. The trade is reluctant to promote the use of these for fear of non-acceptance by the consumer.

Utilisation of a wider range of species may help in tropical forest resource conservation by taking the pressure off timbers which are over-exploited and by leading to more intensive exploitation of timber species in appropriate areas. Freezaillah (1984) points out that up to 93 per cent of tropical forest timber volume consists of lesser-known species and that many such species are currently being burnt or otherwise wasted after logging operations or forest clearance. The need to utilise these species is particularly important in Latin American and African countries where present logging volumes are low. Lists of lesser-known species for these two regions are provided by the French Centre Technique Forestier Tropical (CTFT) in a report prepared for ITTO (CTFT, 1987).

The use of more timber species would reflect a general trend in the tropics for more and more species to be discovered as valuable (Schmidt, in press). Many of the tree species currently destroyed have other potential uses, for example as fast-growing fuel wood species, or sources of medicinal biochemicals. Timber species considered to be commercially valuable are changing constantly although the traditionally utilised species retain their overall importance in international trade.

Promotion of lesser-known tropical timber is carried out by forestry institutes and information services in both producer and consumer countries. Collaborative programmes between national institutions are particularly valuable. CTFT is, for example, working together with INPA (Instituto Nacional de Pesquisas da Amazonia) to improve the knowledge of Brazilian woods.

Problems in promoting lesser-known species include conservatism within the trade, difficulty in species identification, inadequate information on physical and mechanical properties, irregular or inadequate supplies, poor grading and incorrect marketing. Inadequate information on the properties of lesser-known species could be partially overcome by the use and development of data bases such as those maintained by the Royal Botanic Gardens, Kew (RBG, $\mathrm{Kew}$ ) and the Oxford Forestry Institute (OFI).

The ECOS data base at $\mathrm{Kew}$ is being developed to include information on tropical hardwoods which will be of relevance for both conservation and utilisation programmes. OFI's Prospect data base includes data on characteristics and uses of tropical timber species. Wassink and 
Wiselius (1979) give addresses of national timber information institutes for European countries and the USA. Fact sheets on the less commercially important tropical woods are produced by some of these institutes, for example, by Arbeitsgemeinschaft HOLZ E.V., the Wood study Group of F.R.Germany's Timber Information Institute. The Association Technique Internationale des Boix Tropicaux (ATIBT) has recently published technical datasheets on 83 African species. (ATIBT, 1987).

Studies of the use of lesser-known species by importing countries have been carried out for example by Towler (1975) and Kalafatis (1982), both in relation to the UK market. The latter study is particularly interesting in that it reports a survey of the attitudes of UK merchants/importers and end-users to lesser-known hardwoods. The 38 species discussed in the study were defined as "lesser-known" by the participants in the study and included species such as Brazilian mahogany Swietenia macrophylla and ramin Gonystylus spp. which are in fact internationally of primary importance in the hardwood trade. More recently the CTFT report for ITTO includes the results of a survey of foresters, traders and wood users in 23 countries. This shows that there is general interest in the promotion of trade in a wider range of timbers and the need for international cooperation in doing so.

Despite the generally accepted benefits of promoting trade in lesser-known tropical timber species, some conservation problems may result. These are due to the lack of data on levels of sustainable extraction from the wild and natural regeneration of the relatively unknown timbers (unless they are well known in local use). Increased demand may of course lead to over-exploitation. This has, for example, occurred in Brazil where in 1984 kapok Ceiba pentandra was virtually logged out when loggers became aware of the commercial properties of the species being studied at INPA, Manaus (A.D. Johns, pers. comm. 1987). Eight of the species included in the CTFT list of lesser-known species of Latin America are also included in FAO's list of endangered species and provenances. Clearly it would be inappropriate to promote greater commercialisation of such timbers.

\section{TROPICAL TIMBER SPECIES THREATENED BY TRADE}

In discussions of tropical deforestation and conservation the effects of commercial logging are usually considered in terms of ecological disruption and the loss of related animal and plant species. There have been relatively few studies of the effects of logging and international trade on the timber species themselves and the data on tropical timbers threatened by trade are relatively sparse.

Examples of tropical timbers which have become extinct through over-exploitation are hard to find but there are endemic island species which have been brought perilously close to extinction through centuries of commercial utilisation. Diospyros hemiteles, an ebony restricted to Mauritius where one specimen remains, St Helena redwood Trochetiopsis erythroxylon and St Helena ebony Trochetiopsis melanoxylon are examples of species which were severely depleted in historic times.

The distinctive technical and decorative characteristics of major tropical hardwoods have long attracted attention leading to the commercial extinction of valuable timber resources. Uncontrolled logging of certain timbers known in the past as "island woods" including mahogany Swietenia mahogani, rosewoods Dalbergia spp., and West Indies satinwood Zanthoxylum flavum has led to impoverishment and loss of forests particularly in the Caribbean, so that these species have become progressively scarcer (Giordano, 1987). The same is true for the rosewoods Dalbergia spp., ebonies Diospyros spp., and paduaks Pterocarpus spp., of S.E.Asia and India; African mahoganies of the genera Entandrophragma and Khaya; and the choice species of Latin America. Although large areas of unexploited forest resources remain in South America, commercial extraction of valuable species has been taking place in more accessible regions for centuries. Valuable hardwoods such as Cedrela fissilis, Dalbergia nigra, Machaerium spp., Piptadenia spp., and Tabebuia spp. have become very rare in the Atlantic coastal forests of Brazil, for example, and the once common Brazilwood tree Caesalpinia echinata now rarely occurs in native habitats. 


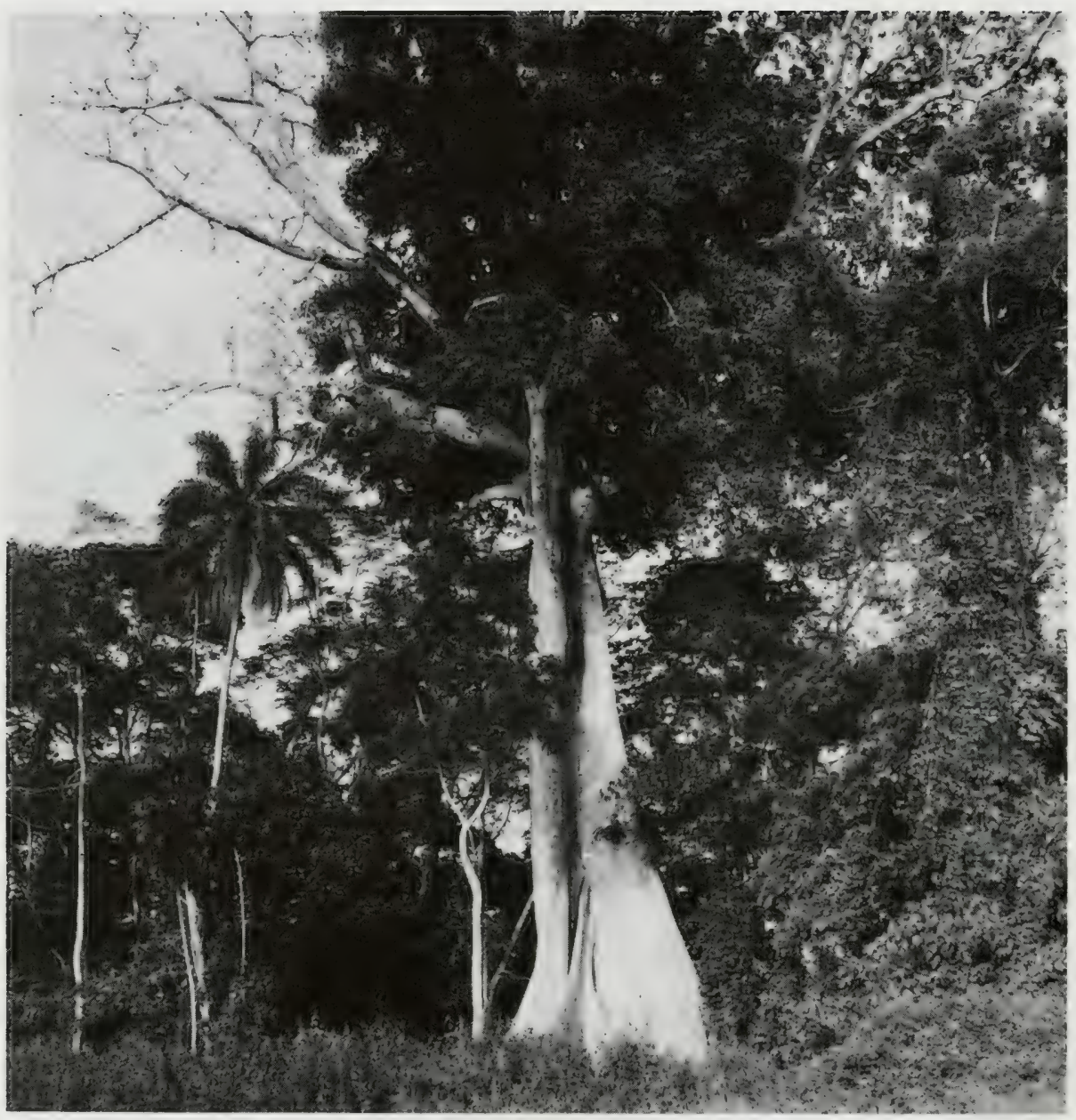

The Kapok tree, Ceiba pentandra, a pantropical species. Wild stands have been depleted in parts of its natural range. Photo: WWF/Prof. U. Rahm 
Table 2: Over-exploited commercial tropical timbers included in the Databook on Endangered Tree and Shrub Species and Provenances (FAO, Forestry Division, 1986)

Abies guatemalensis

Anadenanthera macrocarpa

Aniba duckei

Araucaria angustifolia

A. cumminghamii

A. hunsteinii

Aspidosperma polyneuron

Astronium urundeuva

Bal fourodendron riedelianum

Bertholetia excelsa

Bombacopsis quinata

Brachyleana huiliensis

Cedrela fissilis

C. odorata

Chlorophora excelsa

Dalbergia nigra

Didymopanax morotoni

Dipteryx alata

Entandrophragma angolense

\section{Esenbeckia leiocarpa}

Eucalyptus deglupta

Glyptostrobus lineatus

Gossweilerodendron balsamiferum

Irvingia gabonensis

Joannesia princeps

Juniperus procera

Khaya senegalensis

Lovoa swynnertonii

Machaerium villosum

Mimosa caesalpiniaefolia

Mimosa verrucosa

Nesogordonia papaverifera

Ocotea porosa

Pericopsis elata

Piptadenia peregrina

Plathymenia foliosa

Pterogyne nitens

Schinopsis brasiliensis

Tabebuia impetiginosa

Taiwania cryptomerioides

Taiwania flousiana
Central America (sub-tropical, highland species)

South America

South America

Argentina, Brazil

Australia, Papua New Guinea

Papua New Guinea

Brazil

Brazil, Argentina, Paraguay

Argentina, Brazil, Paraguay

Bolivia, Brazil, Colombia, Peru, Venezuela

Central \& South America

Africa

Costa Rica to Argentina

N. Mexico to N. Argentina, Caribbean

tropical \& sub-tropical Africa

Brazil

Central \& South America (secondary forest)

Brazil

Guinea to Angola, Central African Republic, Zaire, Sudan, Uganda

Brazil, Zaire

Mindanao, Celebes, Ceram, Irian Jaya, Papua New

Guinea

China

West Nigeria to Zaire

Africa

Brazil

Brazil

tropical Africa (savanna)

Africa

Brazil

Brazil

Brazil

West Africa (secondary forest)

Brazil

West Africa

Brazil

Brazil

South America

Brazil

Brazil

Taiwan

Burma, Chile

Note: Most of the species listed above are involved in international trade, some as major commercial timbers. Other species included in the FAO list are potentially important commercial species or are important as relatives of leading timbers. 
Biological species extinction is unlikely to occur as a result of commercial logging. There are however examples of timbers which are considered vulnerable to extinction at a national level where logging has been particularly intense. The list of species in Annexe 1 includes such examples. The number of tropical timbers which are of conservation concern is now quite considerable. Unfortunately there is as yet no centralised source of data on tropical timber species under threat from trade although various lists of species of concern have been compiled either nationally or by international agencies. Species identified as being currently or potentially at risk from commercial trade, at least in parts of their range, include the familiar and valuable tropical hardwoods such as ebony, mahogany, rosewood and teak species.

The most comprehensive international listing of timbers which are of conservation concern is that compiled by the FAO Panel of Experts on Forest Genetic Resources. The Panel of Experts compiled a list of priority species for attention whether for conservation, exploration, evaluation or utilisation. Included in this broad listing are 81 tree and shrub provenances which were identified as endangered at the 5 th session of the panel in 1981. The tropical timber species from this endangered list are given in Table 2. A data book on the 81 endangered species and provenances has recently been published. The foreword to the book points out that, "the list of species included is by no means a complete list of endangered woody species, but represents a cross-cut of those species which the Panel considered should urgently be included in genetic resources programmes". (FAO Forestry Division, 1986).

FAO has been identified as the lead agency for in situ conservation of plant genetic resources by the Ecosystems Conservation Group (ECG), consisting of rrepresentatives of FAO, IBPGR, IUCN, Unesco and UNEP, and the co-ordinating role for this is carried out by the Forestry Department. Clearly the identification of threatened tropical timber species is an important aspect in defining priorities for tropical plant conservation programmes, not least because of the financial importance of these species to the countries where they occur.

Table 3: Tropical timber species included in the IUCN Plant Red Data Book (Lucas and Synge, 1978)

Diospyros hemiteles
$\quad(=$ Diospyros sp. nov.)
Drypetes caustica
Heritiera longipetiolata
Neowawraea phyllanthoides
Persea theobromifolia
Santalum fernandezianum
Serianthes nelsonii
Sophora toromiro
Trochetia erythroxylon
$\quad$ (= Trochetiopsis erythroxylon)
Vateria seychellarum
Vepris glandulosa
Zanthoxylum paniculatum

Note: None of the tropical tree species included in the IUCN Plant Red Data Book is currently of commercial importance for timber, generally because stocks in the wild are too severely degraded. Species other than those listed above may be locally exploited for fuel wood or have been used locally for wood in the past.

\author{
Mauritius \\ Mauritius \\ Guam \\ Hawaii \\ Ecuador \\ Juan Fernandez \\ Marianas Is. (Guam and Rota) \\ Easter Island, Pacific Ocean \\ St Helena \\ Seychelles (Mahé) \\ Kenya \\ Rodrigues
}


IUCN's involvement in the collection and analysis of information on threatened timber species is through the activities of the Conservation Monitoring Centre (CMC). CMC holds data on threatened tropical tree species as part of its computerised data base on threatened plants. Botanical information for the data base has been collected from a wide variety of sources including national lists of threatened plants, published floras and checklists and an international network of correspondents. Data on African and South-East Asian threatened plants is collected by the CMC office based at the Royal Botanic Gardens, Kew. Information on Latin American species is collected by the IUCN-Smithsonian Latin American Plants Project in Washington D.C.

For each plant taxon included in the data base its distribution and conservation status where known are recorded. However no systematic attempt has yet been made by CMC to compile lists of tropical timbers which are threatened by trade. Nevertheless many tropical timbers of conservation concern are recorded in the data base and a sample list is given in Annexe 1. A few examples of tropical timbers which have been over-exploited are included in the IUCN Plant Red Data Book (Lucas and Synge, 1978) and are listed in Table 3.

It has been suggested that, "the difficulties of field identification and the scattered distributions of individual species combine with the rapid removal of vegetation to make a species by species approach impossible", in the collection of information on threatened tropical trees (Roche and Hamann, 1985). Lack of detailed species information is certainly a major problem for many areas of tropical forest but, significantly for any analysis of trees threatened by trade, forest inventories tend to concentrate on species which are of importance to the timber industry. Information on the status of individual timber species should therefore be more readily available.

$\mathrm{CMC}$ is hoping to extend the data it holds on threatened timbers to include information on tropical species, in part by developing further linkages between IUCN and government and university forestry departments.

National lists of tropical timber species of conservation concern have been partially compiled for various countries. A list of 27 "vanishing timber species in the Philippines" is given by de Guzman (1975). This includes valuable timbers such as kamagong Diospyros philippinensis and ipil Intsia bijuga which are protected by law. The status in the wild of the Philippines dipterocarps and other tree species is recorded by de Guzman, Umali and Sotalbo (1986). Lists of vulnerable forest tree species in Camercon and Peru and commonly used tree species requiring conservation action in Peninsular Malaysia are given in a recent FAO report on in situ conservation (Roche and Dourojeanni, 1984). It would be most valuable to assemble similar national information from published and unpublished sources into a centralised data bank.

Forestry legislation yields useful information on species which are subject to special controls because of their rarity or vulnerability to over-exploitation. It thus provides a further source of species information which could be incorporated into an international data base. The Burma Forest Act (1902) as amended, for example lists 17 species which are subject to protection. including Dalbergia oliveri which is considered to be vulnerable, Pterocarpus macrocarpus, two species of Heritiera and three dipterocarps.

A further partial list of tropical timber species which are of conservation concern can be derived from the Appendices of the Convention on International Trade in Endangered Species of Wild Fauna and Flora (CITES). The tropical timber species listed under this Convention are given in Table 4. Data sheets on 17 of the timber species (including several which are sub-tropical) were included in the IUCN Threatened Plants Committee report to the third meeting of the Conference of the Parties to CITES. The relevance of CITES as a mechanism for controlling and monitoring trade in tropical timbers is discussed below. 
Table 4: Tropical timber species included in the Appendices of CITES

\section{APPENDIX I}

Abies guatemalensis

C. America (high mountains)

Batocarpus costaricensis Costa Rica, possibly Panama

Caryocar costaricense Costa Rica, Panama

Cynometra hemitomophylla Costa Rica

Engelhardtia pterocarpa Costa Rica

Guarea longipetiola Costa Rica, Panama, Honduras

Platymiscium pleiostachyum Costa Rica

Podocarpus costalis Philippines, Taiwan

Podocarpus parlatorei Argentina, Bolivia, Peru

Tachigalia versicolor Panama, Costa Rica, Colombia

Vantanea barbourii

Costa Rica, possibly Panama

\section{APPENDIX II}

\section{Guaiacum sanctum} USA, Caribbean, Central America

Pterygota excelsa

(= Basiloxylon excelsum)

Costa Rica, possibly Guatemala

Quercus copeyensis

Costa Rica, Panama

Swietenia humilis

Central America
Local usage, heavily depleted, seed has been exported from Guatemala to USA according to CITES statistics

Not thought to be in local use or international trade

Local usage, no evidence of international trade

Not thought to be in local use or international trade

Used locally but no evidence of international trade

Good quality timber, no evidence of international trade

Not thought to be used locally or in commerce

Not thought to be in trade

Has been used in manufacture of paper pulp

Recorded in local use

Species first discovered in a sawmill sample but not currently thought to be in use

Commercially valuable but heavily depleted. CITES statistics record Japanese imports from Mexico and one transaction between Costa Rica and Canada

Not thought to be in local use or international trade

Used locally in the past

A mahogany species used locally but of little commercial importance. Several transactions are recorded in CITES statistics. 
In addition to the various lists and data sheets on rare and threatened tropical timber species, there are more detailed case studies on the effect of trade in particular threatened species reported in the literature. These include studies on mahogany Swietenia and other genera (Knees and Gardner, 1983), Swietenia macrophylla (Browder, 1986), Zambezi teak Baikiaea plurijuga (Piearce, 1986), and sandalwood Santalum album (Murthy, 1985). Browder's thesis describes in detail the tragically wasteful depletion from nature of a valuable and potentially renewable timber resource, with access to the scarce timber becoming increasingly concentrated in the hands of a few high-volume Brazilian and American co-traders. The race for mahogany has led to extraction from biological and Indian reserves and the use of armed guards to protect forest access roads. Other publications draw attention to the range of tropical timbers which are under threat. For example a report by the US National Academy of Sciences comments on luxury timbers of the family Leguminosae which are facing economic and biological extinction (National Academy of Sciences, 1979). Information on these timbers is summarised in Table 5.

Table 5: Luxury tropical timbers in the Leguminosae: species of conservation concern

\section{Dalbergia spp.}

About twelve species of this genus produce valuable rosewood timber. Although widespread, today the trees are nowhere abundant; all the accessible stands have long been logged out and rosewood has become very scarce. Of the Dalbergia spp. which produce valuable hardwoods, Dalbergia latifolia is the only species which has been established in plantations. These are on an experimental basis in India and Java.

\section{Intsia spp.}

Two species of this genus Intsia bijuga and Intsia palembanica are discussed in the NAS report. Both are native to tropical rain forests from South East Asia to the islands of the south-west Pacific, occurring in wet lowland habitats. The wood of these two species has been so heavily exploited that in most countries few trees are left in natural stands. Some countries such as Malaysia have restricted the export of Intsia wood. Economic extinction is considered to be imminent.

\section{Pericopsis elata}

One of the world's most valuable tropical hardwoods, this species is native to the west coast of Africa where it occurs mainly in pockets of the Ivory Coast, Ghana, Gabon and Zaire. Natural stands are being heavily cut and because natural regeneration is poor and plantation limited, the tree is facing economic and biological extinction.

\section{Pericopsis mooniana}

A highly prized wood native to Asian rain forests from Sri Lanka to New Guinea. It is fast disappearing due to lumbering and land clearing.

\section{Pterocarpus spp.}

Demand for luxury woods from various Asian and African species of Pterocarpus far exceeds supply. None of the species is under extensive cultivation and the native stands are fast disappearing. 


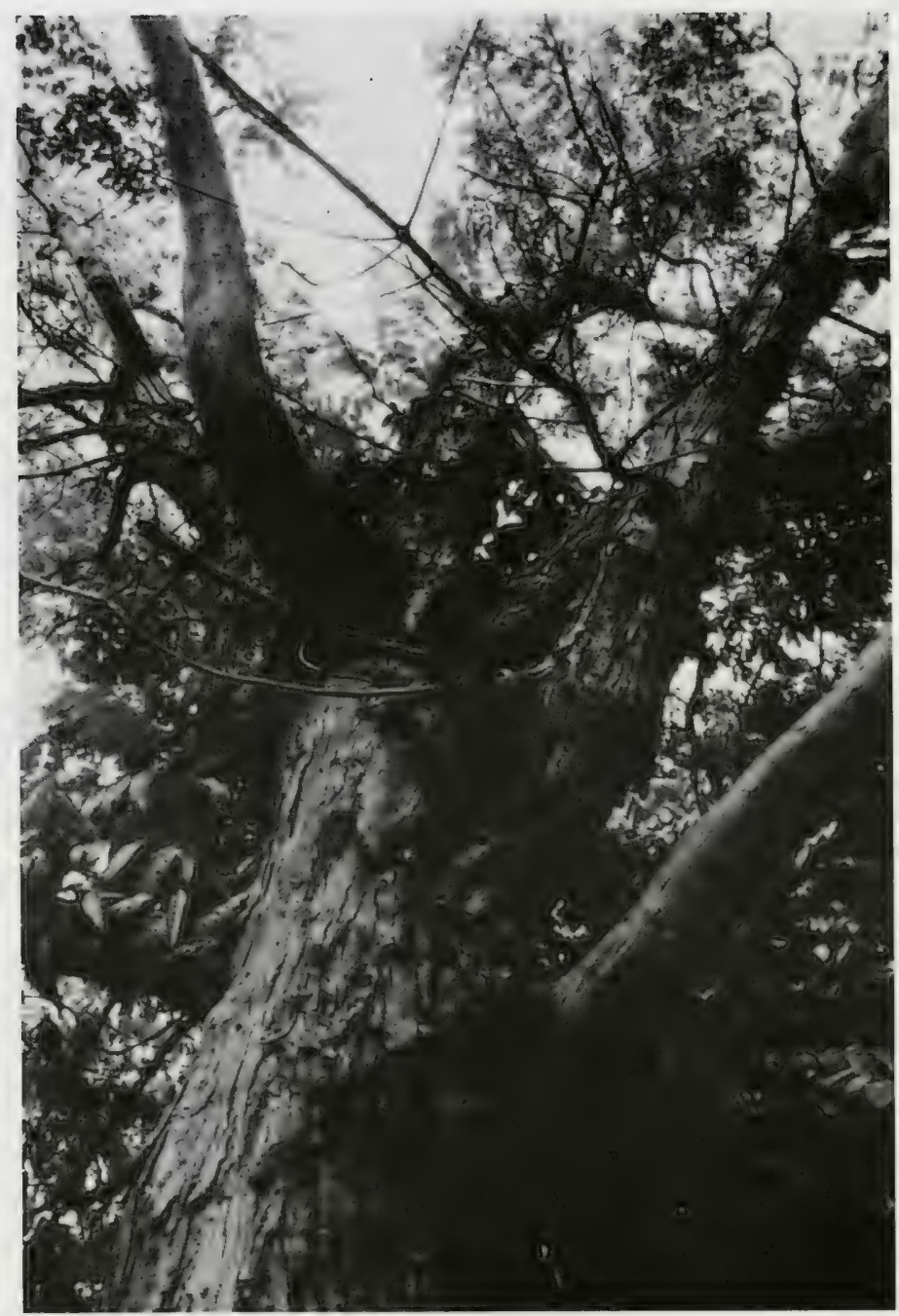

Swietenia macrophylla, a valuable species of mahogany from Brazil. Photo: WWF/P. Forster 


\section{CONSERVATION MEASURES FOR TROPICAL TIMBER SPECIES}

The major tropical forest conservation priority is the in situ conservation of forest resources in legally protected areas. At present only about 3 per cent of the tropical closed forest area is safeguarded in national parks or other protected areas, and many of these are protected on paper only. Frequently species inventories in the areas designated for conservation have not been prepared and it is therefore difficult to assess whether threatened tree species are adequately protected in situ. Forest reserves, i.e. areas which are legally designated for forestry purposes rather than conservation, can provide an important additional conservation resource for tropical timber species where properly managed.

Management of tropical forest resources is becoming increasingly important with the current loss or degradation of more than 11 million hectares per year. At present less than 5 per cent of the productive closed forest is managed in a satisfactory manner for the sustained production of timber. These facts are set out in the FAO Tropical Forestry Action Plan (FAO, 1985) which is an internationally agreed plan for the sustainable utilisation and conservation of the world's tropical forests.

In addition to the pressing need for ecosystem conservation, measures are necessary to prevent the over-exploitation of valuable tropical timber and other economically important species. For endangered tropical timbers such as those which have been identified by FAO (see Table 2) research and management programmes are required with studies of natural and artificial propagation and regeneration (C. Palmberg, pers. comm. 1986). Research programmes have already been initiated for certain heavily exploited species such as that for Triplochiton scleroxylon carried out as part of the West African Regional Hardwood Improvement Programme. This is a joint project involving the Centre Technique Forestier Tropical (CTFT) and the British Institute of Terrestrial Ecology (ITE), which aims to conserve and enhance the resources of indigenous broadleaved trees of West Africa. The ex situ conservation of valuable tropical timbers through the maintenance of genetic material in gene and seed banks and propagation research is essential for the development of plantation forestry.

Improved forest management and the development of tropical timber plantations remain long-term goals in tropical forest conservation. They both form major elements in the promotion of conservation under the International Tropical Timber Agreement (ITTA) a major recent agreement which is discussed further below. For the short term, various forms of international trade controls have been proposed or already exist to prevent the over-exploitation of tropical timber species.

\section{CONSERVATION TRADE CONTROLS}

Increasing commercial pressure on certain species has led many governments to introduce domestic legislation to prevent over-exploitation. In Kenya, for example, it has been noted that the ever-increasing demand for sawn timber for panelling, furniture and cabinet-making has introduced a great strain on the management of many indigenous species such as muli Chlorophora excelsa, camphor Ocotea usambarensis, vitex Vitex keniensis, and muhugu Brachylaena hutchinsit. Recent controls on exploitation of such species introduced by the Government has led to illegal removal of produce with logging carried out at night (Odera, 1984).

Legislation exists in many tropical countries to prevent or control the export of timber at least in an unprocessed form. Such legislation may be enacted partly for conservation reasons and partly to ensure that increased revenue from value-added timber products remains in the producer country. The Philippines, Malaysia, and Indonesia have, for example, all taken steps to trestrict log exports, partly for conservation reasons.

The Philippine Government decided to ban log exports in 1972 and announced measures aimed at reducing $\log$ exports until they were phased out completely by 1976 . For financial reasons the ban has not been fully enforced and log exports have been permitted by quota allocation. 
Exports have dropped substantially, however, from 9.6 million $\mathrm{cu} \mathrm{m}$ in 1970 to below one million $\mathrm{cu} \mathrm{m}$ in 1980. A policy of strict conservation and rational utilisation is considered essential to sustain the wood processing industry of the Philippines (Anon., 1984b). Implementation of legislation has been limited by short-term economic considerations and illegal timber smuggling continues to be a problem. In 1981, for example, it was estimated that the volume of logs smuggled to Japan exceeded one million $\mathrm{cu} \mathrm{m}$.

Nigeria has also banned the export of logs and semi-processed timber out of necessity. According to FAO an area of 285,000 ha was deforested annually in Nigeria between 1976 and 1980 and the export value of forest products declined from \$22 million in 1973 to less than \$1 million in 1983.

In some cases timber export legislation relates to certain species. In Peninsular Malaysia, for example, a ban was imposed on the export of logs of 11 species in 1972 and this was later extended to 16 species. Ghana has a ban on the export of 18 valuable timber species in $\log$ form (see Table 6).

Table 6: Log exports banned by Ghana

Scientific name

Aningeria robusta

Chlorophora excelsa

Entandrophragma angolense

E. candollei

E. cylindricum

E. utile

Guibourtia ehie

Khaya "africana"

Lovoa trichilioides

Mansonia altissima

Nesogordonia papaverifera

Pericopsis elata

Tarrietia utilis

Tectona grandis*

Terminalia ivorensis

Terminalia superba

Tieghemella heckelii

Turraeanthus africana
Trade name

Asamfona
Odum
Edinam
Omu
Sapele
Utile
Hydua
Mahogany
Walnut
Mansonia
Danta
Afrormosia
Nyankom
Teak
Emire
Ofram
Makore
Avodire

* not indigenous

Ghana's log export ban is mainly in force to encourage national wood processing industries but is also seen as a conservation measure. Four species were added to the list in early 1988 . Of these Terminalia superba and Aningeria robusta have been particularly subject to selective and wasteful $\log$ extraction.

Since 1975 Madagascar has banned the export of unworked wood of valuable species such as palissandra voamboana Dalbergia baronii, a tropical moist forest species, and palissandra violet Dalbergia greveana, a species of tropical savanna vegetation. A detailed study of the timber species covered by national legislation in all tropical countries would undoubtedly yield valuable information on species which have been heavily exploited. 
Voluntary action and legislation to restrict the import of tropical timbers by consumer countries has been called for as an additional conservation measure by various voluntary groups. Friends of the Earth-UK has, for example, called for a consumer boycott of tropical forest products from unmanaged forests as part of its tropical forest campaign. The World Resources Institute has promoted a similar ban in the USA and the Rain Forest Information Centre in Australia. Conservation groups are now campaigning for legislation to ban the import of all unsawn logs into European Community member states. This would be particularly valuable in promoting the development of forest industries in less-developed countries.

Calls for consumer action in influencing the tropical timber trade are understandable in view of the present plight of tropical forests and wasteful utilisation of forest resources. Such campaigns, do however, generally suffer from a lack of detailed species information which is needed particularly in view of resistance to controls from trade interests. Resistance from the trade can extend to any restriction on timber commerce. As McNeil (1981) points out, "Timber men fear a tendency on the part of Governments to beset the timber industry with restrictions, controls and marketing straight-jackets (for example, Marketing Boards, check price systems and selective species limitations)."

There is a general argument that over-restrictive controls on the tropical timber trade would be counter-productive to conservation, in that less developed countries will only take steps to conserve their tropical forests if they are seen as a commercial resource. Von Meijenfeldt (1985), for example, points out that, "in many cases merchantable wood makes the forest valuable and, therefore, will act as a kind of protection to the forest ... if tropical hardwood is not used, it will probably be disastrous to the rain forests in the long run". Hansom (1985) considers that no reduction in international trade would be beneficial because, "the ecological problem is much more related to the agricultural exploitation that comes after the logging of forest areas". Although it is important not to remove the economic benefit to be gained from careful management and exploitation of forests for timber, there are clearly valuable timber species which would benefit from trade controls.

It has been argued that exporting countries coulä exert more effective control over the international tropical timber market through the formation of an Organisation of Timber Exporting Countries (OTEC) (Guppy, 1983 and 1984). The aims of this would include the reduction of felling of natural tropical forest and the increase of forest product prices in line with this reduction. At present prices are only high for some of the valuable furniture woods and consequently these are the only species to be individually identified, sorted, extracted and processed with care. It is argued that raising the value of tropical forest products generally through OTEC would lead to increased revenue for tropical forest conservation.

The proposed formation of OTEC has now been overtaken by the establishment of the International Tropical Timber Organisation (ITTO) under the ITTA. It is possible that the ITTA may achieve some of the same aims of an OTEC although it has been argued by some authors (for example Guppy, 1984) that through the ITTA the tropical timber market will continue to be manipulated by the main buyers aiming to keep prices low rather than sustaining timber production in the long term.

ITTA does however have implications for tropical forest conservation, of which the conservation of threatened timber species could become an important part. As such it could be used in conjunction with CITES. This international conservation convention is already being used to prohibit or control and monitor trade in threatened timber species.

\section{THE CONVENTION ON INTERNATIONAL TRADE IN ENDANGERED SPECIES OF WILD FAUNA \& FLORA (CITES)}

CITES is the only international agreement which provides for the control of trade in tropical timber species for conservation purposes. The tropical timber species included in the Appendices to CITES are listed in Table 4 of the present report. International commercial trade in timber taken from the wild of species listed in CITES Appendix I is forbidden for 
Parties, whereas trade in those species listed in Appendix II is controlled by export licence. The licensing of trade in Appendix II species is an important aspect of the management of commercially valuable wild species, allowing for the sustainable utilisation of wild stocks.

Monitoring of trade in CITES species provides an important source of international trade statistics. These are maintained in a centralised data base by IUCN's Wildlife Trade Monitoring Unit (WTMU) at the CMC. Few of the timber species covered by the provisions of the Convention are, however, important in international trade and consequently the trade data collected on them are relatively limited. Fitz-Roya cupressoides and Araucaria araucana, two non-tropical South American timber species are the exceptions to this. Limited CITES trade data are also maintained by WTMU for timber of Guaiacum sanctum and Swietenia humilis.

The strength of CITES in prohibiting trade in over-exploited species is well illustrated by the case of Fitz-Roya cupressoides. This species is one of Chile's most valuable timbers and has been exported since the sixteenth century. Stands in the country are consequently much reduced and confined mainly to inaccessible areas. Fitz-Roya cupressoides is totally protected in Argentina the only other country where it occurs. Natural regeneration of the species is poor and the trees which have been established in cultivation generally produce infertile seed.

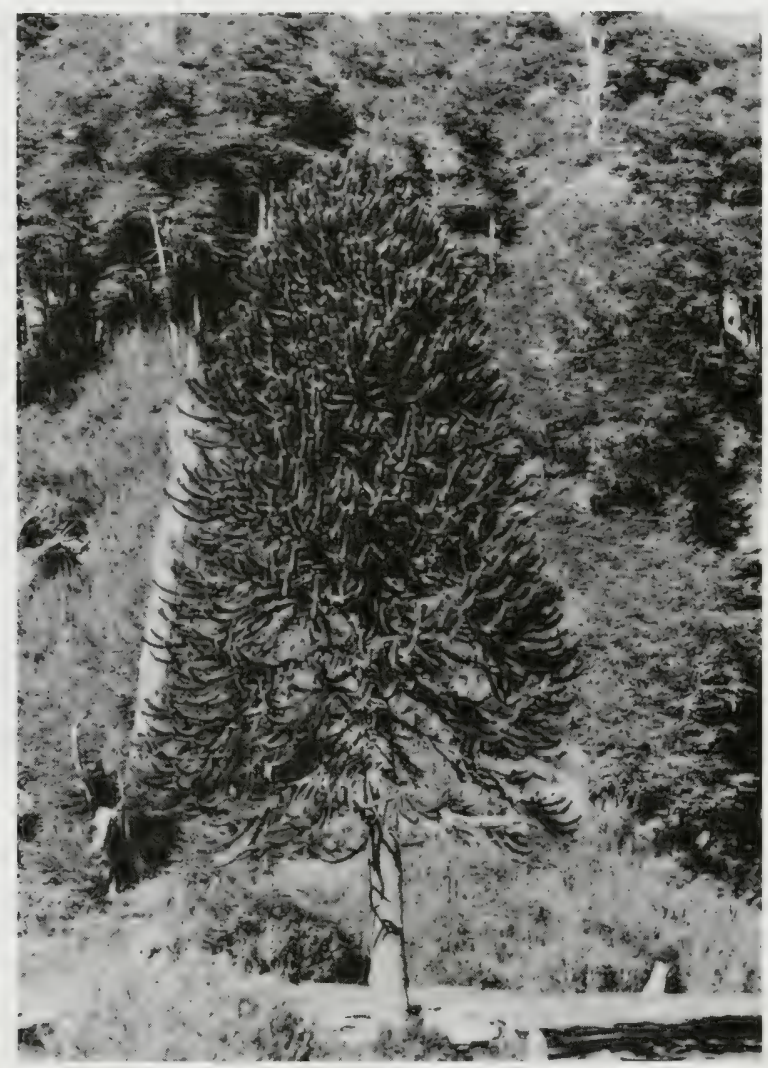

Araucaria araucana, a temperate South American timber species protected by CITES. Araucaria angustifolia, the second South American species, has a tropical distribution and is considered by FAO to be endangered in parts of its range. It is not subject to international trade controls. Photo: WWF/Hernan Torres 
Fitz-Roya was included in Appendix I of CITES in 1973 and is listed as a threatened species under the US Endangered Species Act of 1973. The USA was previously a major market for Fitz-Roya timber and under pressure from commercial interests in Chile the Chilean Government has tryed to open up the international market once more. This was partially successful following a decision to transfer the Chilean coastal population of the species from Appendix I to Appendix II at the 4th meeting of the Conference of the Parties in 1983. Further attempts to downgrade CITES protection for this species were resisted at the 5th meeting of the Parties. At the 6th meeting of the Parties in 1987, an Argentinian proposal to transfer the Chilean coastal population back to Appendix I was accepted.

CITES listing has been recently considered for a range of valuable hardwoods. Draft CITES proposals for Entandrophragma spp., Khaya spp., Swietenia spp, Baikiaea plurijuga, Pericopsis elata, and Gossweillerodendron balsamiferum were prepared following a detailed trade study and extensive consultation involving timber traders, forestry experts and conservation ngos. The proposals have not been formally submitted to CITES although the Ghanian government considered submitting the species proposals which reinforce its national timber export legislation.

Other rare species which may be candidates for listing include valuable timbers used in small quantities by woodworkers, for example pink ivory wood Berchemia zeyheri, rose woods and ebonies, and species considered Endangered by FAO such as the Chinese Coffin tree Taiwania cryptomerioides, a tropical montane conifer.

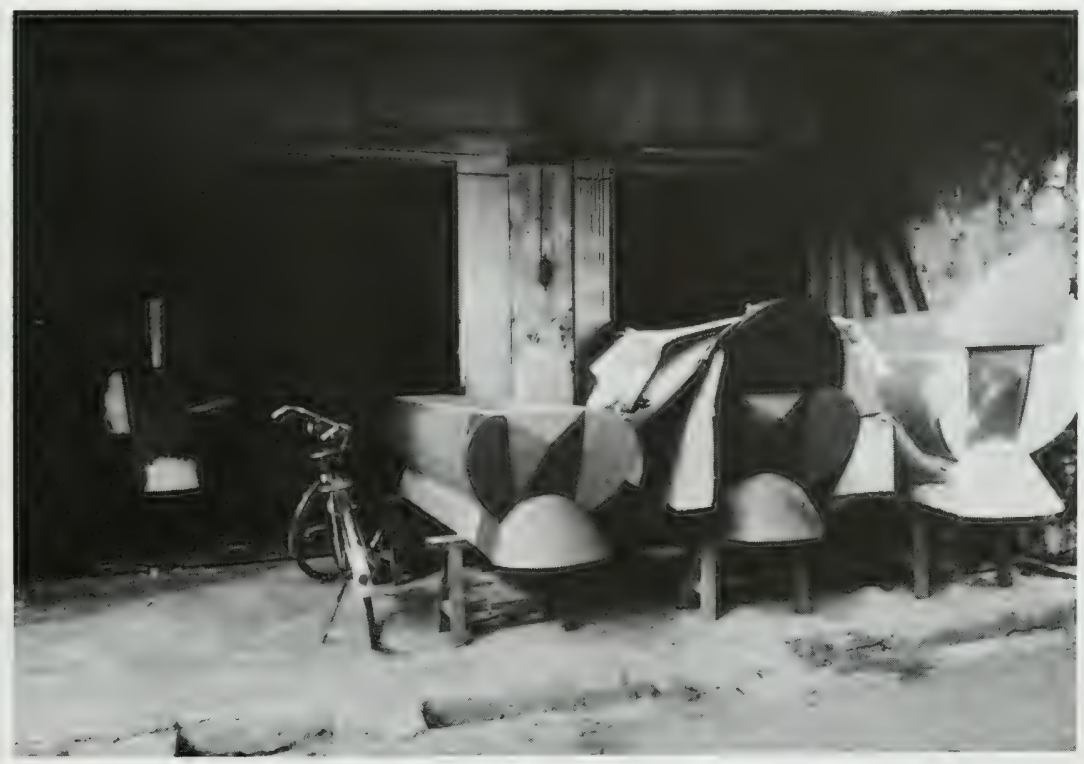

Chinese coffins traditionally made from the wood of Taiwania cryptomerioides. Photo: WWF/Sylvia Yorath 


\section{THE CONSERVATION ROLE OF THE INTERNATIONAL TROPICAL TIMBER ORGANISATION (ITTO)}

The International Tropical Timber Organisation (ITTO) was established under the International Tropical Timber Agreement (ITTA) which came into force on 1 April 1985. 41 countries are now party to the Agreement, including both tropical timber producer and consumer nations. ITTA is a commodity agreement, drawn up under the aegis of UNCTAD, and as such is unique in having strong environmental provisions. A useful background document on ITTA and its prospects for conservation is provided by Hpay (1986).

The environmental potential of the Agreement has been recognised as one of its major strengths by governments and environmental groups. Timber trade organisations have also welcomed the opportunity to participate in conservation initiatives under the Agreement and recognise the use of the ITTO for conservation debate.

The ITTO works through its Council and three Permanent Committees with a small Secretariat based in Yokohama, Japan. The Permanent Committee on Reforestation and Forest Management is the Committee most directly concerned with conservation within the Organisation. At the third meeting of ITTO held in November 1987 guidelines were agreed for the work of this Committee. Conservation objectives will be achieved through:

a) the development of management systems for tropical forests which incorporate the sustained production of timber and other forest resources and long term conservation of genetic resources and biodiversity;

b) the development of management systems for the rehabilitation of degraded lands;

c) the development of national forestry policies which include measures for conservation, sustainable utilisation and rehabilitation of forest lands.

The Permanent Committee on Economic Information and Market Intelligence is concerned with data collection, some of which could have important implications for the monitoring of trade in threatened timber species. The specific functions of this Committee are as follows:

a) to keep under review the availability and quality of statistics and other information as required by the Organisation;

b) to analyse the statistical and other specific indicators, as identified in the Agreement, for the monitoring of the international tropical timber trade;

c) to keep under continuous review the international tropical timber market, its current situation and short-term prospects;

d) to make recommendations to the Council on the need for, and nature of, appropriate studies on tropical timber, and monitor and review any studies commissioned by the Council;

e) to carry out any other tasks related to the economic, technical and statistical aspects of tropical timber assigned to it by the Council;

f) to assist in the provision of technical co-operation to producing countries to improve their relevant statistical services.

The statistical data and other information needed for timber trade monitoring under ITTA have already been identified and are given as Annexe $C$ to the Agreement. The information considered necessary is quite detailed including for example monthly data for export and import volumes by species. The data are intended primarily to facilitate and promote trade but, if sufficiently detailed, may also be useful in monitoring trade in species for conservation purposes.

The international agencies likely to be involved in the collection of data under the ITTA are the Forestry Department of FAO, ECE Timber Committee and ITC. The present and proposed data services of these organisations are discussed below. One particular aspect of monitoring which should be instigated under the ITTA is the preparation of detailed trade studies on individual tropical timber species of conservation concern. The need for such studies is considered a priority by conservation ngos and would be a useful support to the conservation objectives of ITTA. 


\section{DATA ON THE INTERNATIONAL TROPICAL TIMBER TRADE}

International trade in tropical hardwood species is depleting stocks in the wild at a rate which far exceeds the establishment of hardwood plantations or the management of natural forests. Quantification of the hardwood trade for conservation purposes has scarcely been carried out to species level and very few trade studies for particular species have been published. Monitoring of tropical timber species in trade would be desirable both to strengthen arguments for and provide the basis of the management of wild stocks of valuable species.

\section{CURRENT SOURCES OF DATA}

Accurate and up-to-date data on the international tropical timber trade are notoriously difficult to come by. Traditionally the lack of transparency in the trade has been due to the fact that the enormous product group has been controlled by relatively few companies who operate through vertically integrated trade chains. The exporters remain aware of the market situation through information fed back from the parent companies and the coltrolling companies have all the information they currently require. Weakening of traditional trade routes and practices is however now leading to calls for more specific and immediate trade data.

The primary published sources of data on tropical timber trade are the national statistics on imports and exports collected by Customs services. Data are aggregated under Customs commodity headings according to the SITC or CCCN systems which give some broad groupings of timbers and separate a few of the major species in trade by name (see Table 7). Import and export statistics at a national level are useful as an overview of the international tropical timber trade but shed little light on the volume of trade in individual species.

The accuracy of any trade statistics is of course open to question and this is certainly the case for the available data on the tropical timber trade. The various explanations for inaccurate timber trade statistics are identified by Durst, Ingram and Laarman (1985). An empirical study based on UN Commodity Trade Statistics carried out by these authors showed that for trade in hardwood logs and lumber, reports of exporting countries and importing countries are frequently in serious disagreement.

One of the main reasons for disagreement between export and import statistics is that commodities are differently measured or inconsistently defined by trading partners. Both the names used for particular timbers and the measures recorded in trade vary widely. As Nectoux (1985) pointed out, "similar wood types can have different names from different geographical regions and importing names can differ between European countries. For instance Customs statistics sometimes classify Philippine luan (similar to meranti types) in mahogany imports instead of putting them in meranti imports."

Definitions of timber products also vary considerably in the trade. FAO has produced a standard reference for work on timber statistics. The comprehensive classification and set of definitions it provides were prepared to facilitate comparison between different systems, such as between trade and production figures and between different countries and regions, and as a reference for the development of new statistical systems (FAO, 1982).

The existing services which provide data on the tropical timber trade are not designed in relation to species conservation. As a regular service, FAO provides the main international source of published data on tropical timber trade, based on Customs data which is rarely detailed to botanical species level. Many other sources of tropical timber trade exist but again rarely break down the data to the level which would be useful for conservation purposes. 


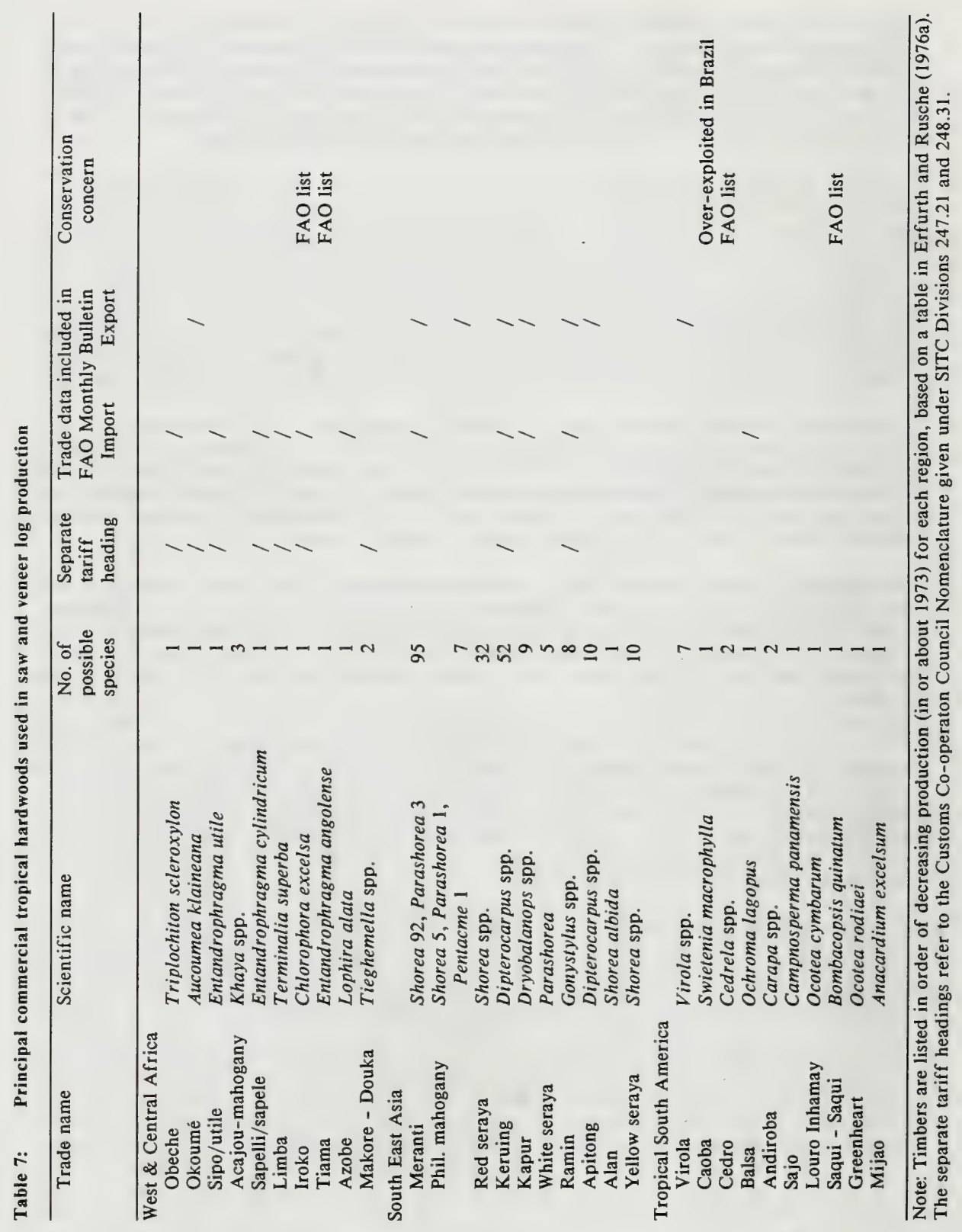




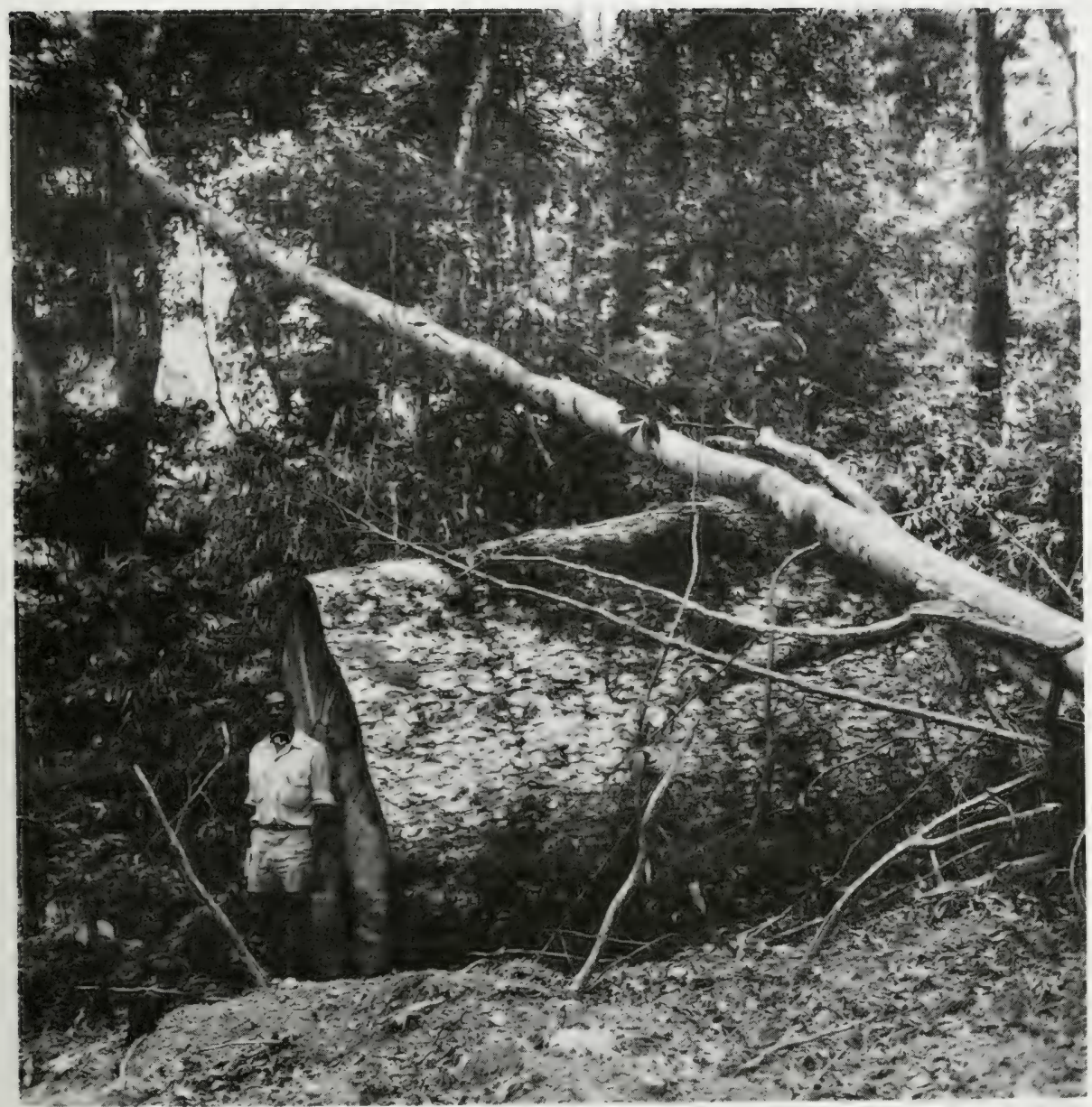

Felled timber of Entandrophragma in the Ivory Coast. Photo: WWF/Prof. U. Rahm 
At present FAO provides the main tropical timber trade monitoring service. This is primarily through the production and publication of the Monthly Bulletin on Tropical Forest Products in World Timber Trade. Monitoring activities were initiated by FAO after the 1974 world recession when the tropical timber trade, particularly of producing countries, experienced major problems. At that time, several countries had already computerised their trade statistics, and others were about to do so (UNCTAD, 1981).

The Monthly Bulletin provides coverage of the most recent available information on monthly exports and imports, their comparison with previous periods, major trade flows, and reference to major events and developments in the market place. The information is intended to be market-oriented and to support tropical timber production and trade in developing countries.

The monthly trade data included in the Monthly Bulletin relate to Customs commodity headings and not to true species. Information on some broad categories of timbers such as ebony, teak, lignum vitae and meranti lauan is provided by some countries.

At present only around 20 countries regularly provide FAO with data for incorporation into the Monthly Bulletin. Of these, 11 are importing countries. There have been problems maintaining contact with the institutes which provide the data and so information flow has been unreliable. Data are provided by Trade Departments rather than Forestry Departments and there is no direct contact with Forestry Departments in the compilation of the information. The African Timber Organisation co-ordinates the provision of data for its member countries. FAO has not attempted to standardise the data provided and countries send what is available. The information sent to FAO is generally in the form of computer print outs except for that provided by Japan which is sent on microfiche. The data are computerised by FAO prior to publication.

At present the Monthly Bulletin can be used to detect broad trends and monitor changes which are taking place in the trade. It may be possible to pick up the effects of trade bans for example and to ascertain what new sources are used when national bans are applied elsewhere. As the major source of international tropical timber trade data, however, the Monthly Bulletin provides only limited information with relevance for species conservation.

ITTO proposes to promote and standardise the collection of data for the Monthly Bulletin. This would be primarily to facilitate trade and the provision of more detailed species information would be welcomed by timber traders. It could also be useful for conservation purposes.

\section{INTERNATIONAL TRADE CENTRE UNCTAD/GATT (ITC)}

The Trade Information Service of ITC is a major source of international data on the tropical timber trade. The primary function of ITC is to help lesser-developed countries expand their export trade and the Trade Information Service supports this function. ITC is concerned with the marketing of manufactured products, rather than raw materials, as a means of promoting economic development.

The Trade Information Service consists of four units, the Trade Documentation Service (library), Electronic Data Processing Unit (EDPU), Trade Information Research Unit and Trade Information Supply Unit. The first three of these units are the tools by which the Supply Unit is able to answer enquiries and also prepare market briefs in anticipation of a number of enquiries concerning a particular product.

The trade information collected and disseminated by the Trade Information Service is organised according to Customs commodity headings under the SITC classification. The EDPU data base consists of national trade statistics stored by SITC codes, giving data on the volume and value of products in trade. The data for this are provided by on-line access to the 
COMTRADE data bank of the UN Statistical Office (UNSO). So far, nearly 200 countries and territories are reporting their yearly import/export statistics to UNSO based on their Customs records (mostly sent as magnetic tapes).

ITC does not publish regular information on the tropical timber trade but rather deals with specific requests for information. Reports on trade in particular products are published in the ITC journal, International Trade Forum, and in reports of special surveys. A feasibility study carried out for the Market News Service of ITC looked into the provision of detailed tropical timber information on a regular basis, as a joint service with ITTO. The study showed that detailed information on trade, availability and acreage of particular species is not currently available.

The study showed a willingness on the side of the trade to supply unpublished information. This would be a very useful source of additional information as the data processed by government trade departments have lost their immediacy and the timber trade associations will only release the information they hold if it is considered beneficial to their members. The study envisaged a network of about 30-40 correspondents around the world supplying timber trade data. They would monitor trade in the key consumer markets such as Europe, Japan, Korea, Taiwan and the USA. ITC's Market News Service at present has offices in Boston, USA and Geneva and is negotiating to have a third office in Japan or elsewhere in S.E. Asia. Contacts in producer countries would provide expert information on the availability of goods, trade regulations, export duties and on the freight-side of trade.

Certain key species would be identified for monitoring purposes, selecting major items from the exporting countries, probably concentrating on Indonesia, Malaysia, Papua New Guinea, Central \& South America and West Africa. The list of species would be sufficiently fluid to reflect changing trends in consumer patterns and would cover about 75-80 per cent of the trade excluding the "minor" species.

The planned information service would be provided in co-operation with ITTO as an extension of ITC's existing service to less-developed countries. It is felt that because of ITC's neutral position it is well placed to process the information from traders, who are coming under pressure to be more transparent, and to supply it to wider interests such as aid agencies, planning organisations, conservation and utilisation bodies. The information service will primarily facilitate trade interests and provide price information but, depending on the choice of indicator species, may provide a valuable source of data for species-conservation monitoring and conservation planning.

\section{EXAMPLES OF REGIONAL TIMBER DATA BASES}

\section{Europe - Timber Committee of ECE}

The Timber Committee of the Economic Commission for Europe (ECE) provides an information base on forest products markets and the factors influencing it, and provides an authoritative and objective assessment of what takes place in the market and short-term prospects. As back-up to the Committee's market discussions, its secretariat (the timber section of the FAO/ECE Agriculture \& Timber Division) has responsibility for the collection and analysis of statistics and other market information (UNCTAD, 1981).

The UN Timber Bulletin for Europe provides information on monthly prices for selected forest products (published every four months), trade flows of forest products (one issue a year) and forest products production, trade and prices (two issues a year). Information is also published on annual forest products markets and prospects for the following year. Information is aggregated according to SITC categories. The Timber Committee of the ECE is considered to be one of the major sources of timber market intelligence along with the Forestry Department of FAO. "Few other institutions or agencies in this field, if any, have carried out the functions of collecting, collating and disseminating information on the tropical timber market as 
regularly and as much in depth as these two bodies" (UNCTAD, 1981). It would appear, however, that the trade data published by the Timber Committee are not sufficiently detailed to provide for species monitoring for conservation purposes.

\section{Africa - The African Timber Organisation (ATO)}

The ATO currently co-ordinates the provision of data for FAO's Monthly Bulletin. A report published in 1984 (Anon., 1984a) gives information on the forest resources, administration, timber production, commerce and marketing for the 11 member countries, mentioning the main commercially important species. The report recommends that a producers' association be formed with government involvement from each country. One of the aims of this association would be to assist the ATO by maintaining a statistical information system.

\section{South Asia - Association of South East Asian Nations (ASEAN)}

ASEAN has been considering the establishment of a permanent ASEAN Timber Bureau which would have as one of its main objectives the collection, monitoring, exchange and dissemination of detailed timber market information. A meeting to discuss this was convened at the FAO Regional Office, Bangkok in November 1986 by the FAO/UNDP Asia-Pacific Forest Industries Development Group. The meeting recommended that in the establishment of ATB:

a) National timber market data management centres should be set up or strengthened.

b) A system for collection of national and international timber market information should be created.

c) Arrangements for an ASEAN timber market data management system should be made.

d) Close links should be established with the Market News Service of ITC, and other organisations such as ITTO.

e) Appropriate training, consultancies, and sub-contracts and production of monthly bulletins should be included in the project.

\section{Southeast Asian Lumber Producers Association (SEALPA)}

SEALPA was formed in 1975 by the national timber trade associations of Indonesia, the Philippines and Malaysia (Sabah), and was later joined by Papua New Guinea. The main objectives of SEALPA are to stabilise the tropical hardwood log export market, to promote the growth of timber processing in these countries, to standardise grading rules and to promote reforestation. SEALPA is involved in regular consultations and exchanges of information (Anon., 1984b).

\section{Latin America and the Caribbean}

The recently established Latin American and Caribbean Forest Information Network (RIFALC) includes in its aims, "to co-ordinate and integrate at regional level, the efforts that different units and/or forest information networks do in the different countries". It is not known to what extent RIFALC will collect trade data.

The Instituto Forestal Latinoamericano (IFLA) in Venezuela has an interest in regional timber trade issues and has published analyses of the Latin American timber trade (see, for example, Centeno, 1985). 


\section{OTHER SOURCES OF DATA}

Various forestry institutions, trade organisations and university departments collect and analyse data on international tropical timber trade although this is rarely to species level. Examples include the Association Technique Internationale des Bois Tropicaux (ATIBT), a leading professional organisation involved in the compilation of data on tropical timbers, and Center for International Trade in Forest Products (CINTRAFOR). CINTRAFOR, at the University of Washington's College of Forest Resources, maintains a data management service for international trade statistics known as INTRADATA. One of the main objectives of INTRADATA is to gather together the various statistical series on forest products throughout the world and organise them into a single system which is easy to use and allows cross-referencing and comparison. The data base incorporates FAO forest product data, including the information in the Monthly Bulletin and data from a variety of other sources. Other potential sources of useful trade data that are less well known, such as ports, local governments and private organisations, are also being explored.

A second objective of INTRADATA is to develop, through research projects and contacts with foreign organisations, new series of data which are not maintained elsewhere. INTRADATA does not currently maintain information on the tropical timber trade by species.

\section{Published studies on the tropical timber trade}

In addition to the regular statistical data on the tropical timber trade such as those held by FAO, special published studies provide a valuable source of information. Particularly noteworthy are the very detailed studies on wood species from African and South American tropical moist forests published by FAO ten years ago (Erfurth and Rusche, 1976a and 1976b). More recently various studies have been published on the tropical timber trade of importing countries, and there have also been several studies of trade in particular species as mentioned on page 13.

The detailed trade studies carried out by FAO were prepared to enhance tropical timber utilisation and resource management. They are based on analysis of available statistical data and also take into account information on occurrence and uses of species. Both commercially important and lesser-used species are covered by the studies, commercial species being defined as those produced in quantities of over $1000 \mathrm{cu}$ m per year.

The appendices to the reports include annual statistics by species on log production (removals), $\log$ exports and sawn wood exports. Also given in the appendices are comprehensive lists of timber species with their occurrence and local names. 217 species are given for Africa and 473 for South America. The lists were prepared using national production statistics and also by screening specialised literature. A draft list is also available for South East Asia (Erfurth, in litt., 1985).

Although these comprehensive regional studies are now out of date, they contain invaluable information as a basis for further detailed studies or for the development of a computerised tropical timber data base.

Brief studies of the tropical timber trade, relating to various countries, including European countries, USA, and several exporting countries, together with papers on general aspects of the international trade are included in the publication, Tropical hardwood utilisation: practice and prospects (Oldeman, 1982). This publication is the proceedings of a seminar, on the utilisation of hardwoods, held in Amsterdam in 1979. Other recent national studies include those by Bull (1985), a review of UK Government trade statistics for 1852-1984; Nectoux (1985), a study of the UK tropical timber industry; and Von Meijenfeldt (1985), a study of the Netherlands tropical hardwood trade. These three examples do not include detailed species information, although they do refer to the major tropical hardwoods imported. A preliminary report on Japan's tropical timber trade with South East Asia has been prepared (Holliman et al, 1987). An analysis of the European tropical hardwood trade has also recently been published (Nectoux and Dudley, 1987). 


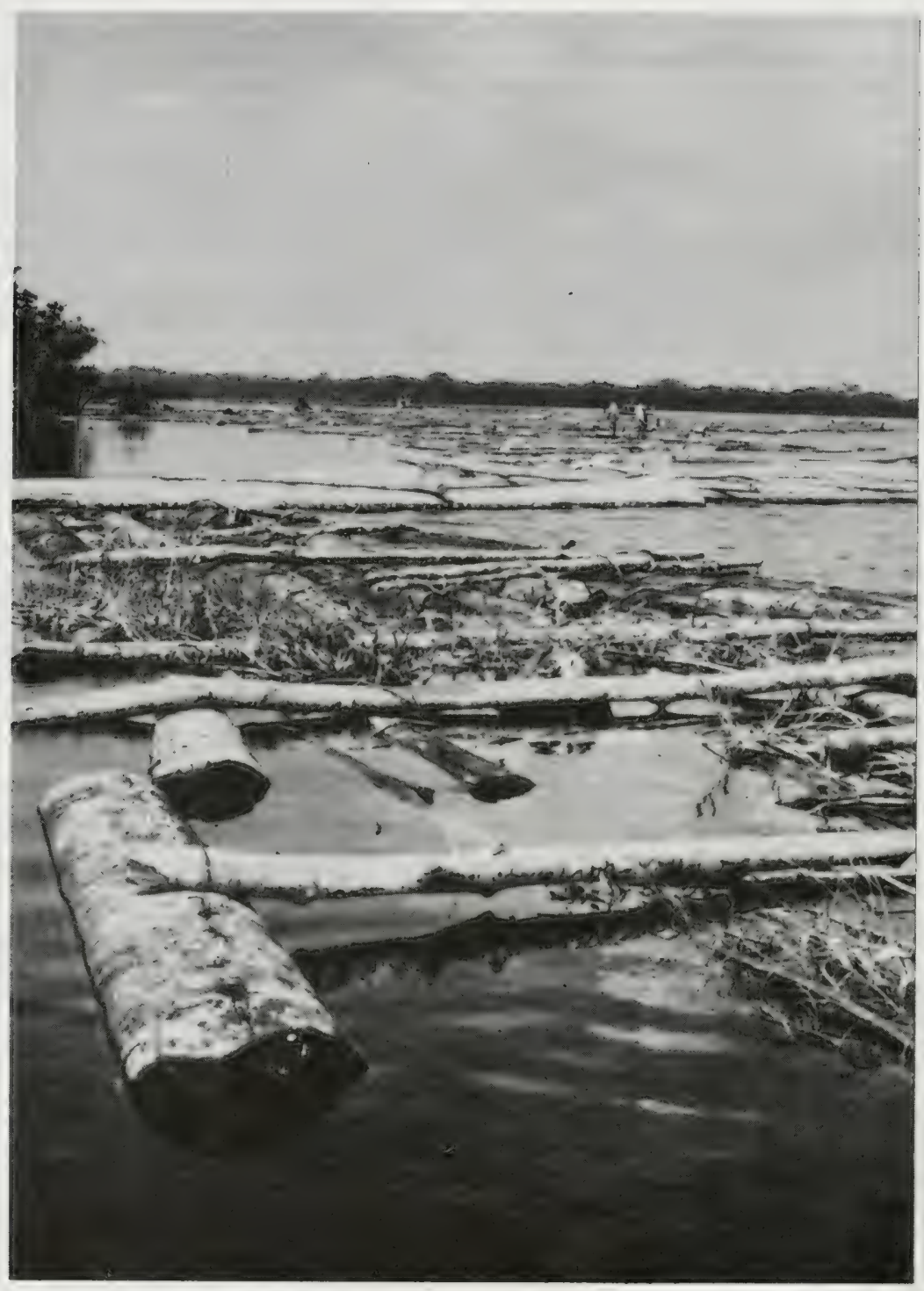

Logs transported downstream for processing on the River Amazon, Brazil. Photo: WWF/Oliver Phillips 


\section{THE NEED FOR FURTHER TROPICAL TIMBER DATA FOR CONSERVATION PROGRAMMES}

The emphasis in tropical forest conservation programmes is on ecosystem conservation through the establishment and management of protected areas. As an important back-up to ecosystem conservation, data on threatened species are required, both to provide indicators of general habitat loss and to ensure that valuable species are protected in situ. For species of actual or potential economic value, intra-specific genetic variation must also be conserved as far as possible.

Timber species have the advantage in the preparation of lists of threatened plants of being relatively well known, at least to forestry departments, of ten through the inclusion in forest inventories.

Roche and Dourojeanni (1984) point out the necessity of establishing a database on tropical woody genetic resources before conservation monitoring can be carried out and, that for such resources, "almost everything has yet to be done including knowing more about them and cataloguing them". They suggest that databases be developed nationally and that a network for storing information should be developed at the international level. Lists of exploited timber species should be prepared by national forest services which have substantial unpublished information of ten not available to scientists outside the services.

The collection of information on threatened tropical timber species is considered a priority by international conservation organisations. Information is needed on the status of species in the wild and in cultivation and on forestry policies relating to their use and conservation. Documentation on the levels of trade in certain species is considered essential, particularly for high-value veneer quality hardwoods. As far as possible information is required on provenance of timber entering trade, system of logging used, quantity used for export and for local consumption.

Roche and Hamann (1985) in a paper presented to the IX World Forestry Congress, made the following points:- lists of tree species, endangered in whole or part of their ranges, as compiled by FAO, IUCN and other agencies need to be extended and refined. Each country should compile its own list of endangered tree species. Forest services and institutions should give higher priority to monitoring tree species threatened by over-exploitation. CMC has an important role to play in co-ordinating regional data centres.

In order for trade monitoring efforts to be beneficial for conservation purposes, data would be needed on the status in the wild, levels of production and levels of international trade in species recognised to be of conservation concern. A prerequisite for any trade monitoring would be to establish a list of tropical timbers threatened by international trade in at least part of their range. The FAO list of endangered timber species and provenances provides a good basis for this and could be supplemented by lists provided by national forestry services and from other sources. It would be beneficial to have a mechanism for international agreement on a list of species threatened by trade, for example through review and approval by ITTO.

Existing data on international trade are not currently available in published form on a regular basis for most species. The species data which are compiled and published, for example in the FAO Monthly Bulletin, cover only the most important commercial timbers. Certain of these major timber species are in fact of conservation concern (see Table 7) and so trade monitoring is already a possibility for some timbers considered to be under threat. It would be beneficial if, through ITTO, countries could be called upon to improve and standardise the data supplied for the Monthly Bulletin and to extend the data provided on species. Again international agreement on a list of species of conservation concern would be useful for this purpose.

In compilation of national trade statistics it should be possible to harmonise the species data provided. At present the species chosen for detailed recording appear to be selected on an economic basis. In the UK Customs statistics, for example, for a hardwood to be included, its
import value must have exceeded $£ 2.5$ million in the previous year and a request for its 
inclusion be made by the relevant trade association (Bull, 1985). As Pleydell (in litt. 1987) points out, statistics of importing countries vary considerably in the coverage given to individual species and this is normally restricted to timbers which have been historically important in trade. Export statistics from producer countries are usually more comprehensive in species coverage but difficult to obtain and out of date.

The present inadequacies of tropical timber trade statistics are widely recognised and there are moves at regional and international level to improve the provision of data. The improved flow of trade data is a major component of ITTA which should be an important mechanism for promoting the collection and dissemination of data and improving international standards and compatibility. Through the Agreement national tropical timber data reporting should be improved both for importing and exporting countries. The need for this has been recognised for example by Bull (1985) who recommends for the UK that:

a) greater precision is required in Customs statistics: in specifying imported timber species;

b) quantities of hardwood from around the world must be surveyed, to identify continuous sources of supply and over-exporting.

Most of the calls for better tropical timber data are to facilitate trade but more accurate timber trade information to species level should aid conservation monitoring. It is unlikely however that monitoring for trade purposes will cover the full range of lesser known species involved in international commerce. The proposed ITC tropical timber data service discussed above, for example, will aim to cover the commercial species which account for 75-80 per cent of the international trade and will exclude the remainder which is in lesser known species (Kaarsegard, pers. comm. 1987). For conservation purposes, a specific data system may be required to monitor the lesser known species which enter international trade.

The extension of CITES coverage to include a wider range of tropical timber species in Appendix II of the Convention could be an excellent way to facilitate monitoring of vulnerable timbers in international trade. Facilities for recording trade in CITES species already exist at national level and internationally through the data base maintained by WTMU.

WTMU's capability to monitor tropical timber trade is facilitated at present by access to the threatened plants data of the CMC and also through co-ordination of the TRAFFIC Network. There are nine TRAFFIC offices some of which have started to collect information on the tropical timber trade. TRAFFIC (Germany) has recently sent a questionnaire to all German importers of tropical hardwood and TRAFFIC(USA) is currently compiling a list of publications relating to the US tropical timber trade. TRAFFIC(Japan) is likely to become particularly closely involved in timber trade monitoring through association with the ITTO headquarters based in Yokohama, Japan.

\section{MEETING CONSERVATION DATA NEEDS}

At present it is difficult to provide a clear picture of conservation aspects of the international tropical trade not least because the trade is complex and diverse. The range of species involved and the effect of trade on individual species is a subject area which requires much more extensive work. There is no doubt a demand for small quantities of rare and prized timbers which places a strain on wild populations and even the more widespread and traditionally valued timbers are now of conservation concern.

Information does exist on the status of timbers in the wild and to a lesser on the status in trade but it is difficult to relate the two sets of data. Definition of terms is part of the problem. Lists of endangered species, commercially important timbers and lesser-known timbers subject to trade promotion overlap causing confusion as to the actual status of the species concerned. Nevertheless there is a need to look further at the biological and trade data which do exist, to standardise the information as far as possible and to establish a basis for monitoring trade in threatened species. This would be a significant step in recognising that tropical hardwoods are too valuable to be lost. 

IUCN CONSERVATION CATEGORIES

This list is based on a print-out from the threatened plants database of the IUCN Conservation Monitoring Centre's Threatened Plants Unit (February 1988). Only species which have an IUCN threatened category for at least one country have been included, and geographical records are only given for countries where the species is known to be under threat. The database is not fully comprehensive in terms of species coverage, and is routinely updated as new information becomes available. Information on conservation status is based on data from published sources and on correspondence with specialists who have field knowledge of the plants concerned. The IUCN conservation categories given are:

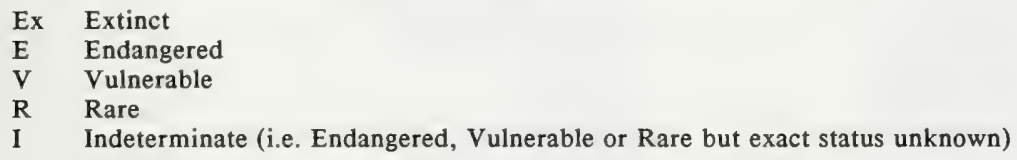

\section{DIPTEROCARPACEAE}

Dipterocarpus gracilis

\section{Dipterocarpus hasseltii}

Dipterocarpus insignis

Dipterocarpus retusus

Hopea brevipetiolaris

Hopea chinensis

Hopea discolor

Hopea erosa

Hopea exalata

Hopea hainanensis

Hopea jacobi

Hopea mollissima

Hopea sangal

Neobalanocarpus heimii

Parashorea chinensis

Shorea assamica

Shorea cara

Shorea disticha

Shorea ovalifolia

Stemonoporus affinis

Stemonoporus ceylanicus

Stemonoporus elegans

Stemonoporus lanceolatus

Stemonoporus petiolaris

Stemonoporus reticulatus

Stemonoporus revolutus

Stemonoporus rigidus

Vateria macrocarpa

Vateria seychellarum

Vatica bantamensis

Vatica guangxiensis
Bangladesh (Chittagong) I,

Philippines R, Java (central \& west) I

Philippines R, Java (Jemba area,

Janlappa) I

Sri Lanka (south-west) R R

China R R

Sri Lanka (Kurunegala) V V

China E E

Sri Lanka (Hiniduma; Ratnapura Dist.) R R

Tamil Nadu (Tirunelveli Ghat) I I

China V V

China E E

Karnataka (Coorg) I I

China E E

Java (Janlappa NR) I -

Pen. Malaysia I I

China R R

China R, Vietnam $\mathrm{V}$

Java (Leuweung Sancang NR) I I

Sri Lanka (Hiniduma; Gilimale) R R

Sri Lanka (south-west) I I

Sri Lanka (Knuckles Range) V V

Sri Lanka (Ratnapura District) V V

Sri Lanka (Adam's Peak Range) R R

Sri Lanka (Kuruwita Korale) R R

Sri Lanka (Kitulgala; Gilimale) R R

Sri Lanka (Hiniduma) V V

Sri Lanka (Ratnapura District) $R \quad$ R

Sri Lanka (Ambagamuwa, Kandy District) $R \quad R$

Tamil Nadu I I

Seychelles E E

Java (Ujung Kulon) E E

China E E 
Vatica mangachapoi

Vatica xishuangbannaensis

\section{MELIACEAE}

\section{Aglaia argentea}

Aglaia barberi

Aglaia canarensis

Aglaia maiae

Amoora dasyclada

Cedrela balansae

Cedrela oaxacensis

Cedrela odorata

Cedrela weberbaueri

Dysoxylum arborescens

Dysoxylum beddomei

Dysoxylum ficiforme

Dysoxylum kuskusense

Dysoxylum pachyphyllum

Dysoxylum patersonianum

Entandrophragma utile

Guarea cedrata

Guarea macrophylla

Guarea pyriformis

Guarea rhopalocarpa

Guarea thompsonii

Khaya anthotheca

Khaya grandifoliola

Khaya ivorensis

Khaya senegalensis

Lovoa trichiloides

Owenia cepiodora

Swietenia macrophylla

Swietenia mahagoni

Toona calantas

Toona ciliata

Trichilia adolf $i$

Trichilia chirriactensis

Trichilia cuneifolia

Trichilia pittieri

Trichilia pungens

Trichilia quadrijuga

Trichilia triacantha

Turraea ad janohounii

Turraea decandra

Turraea fischeri

Turraea ghanensis

Turraea laciniata

Turraea oppositifolia

Turraea rigida

Turraea trichopoda

Xylocarpus moluccensis
China V

China R

Queensland R

Kerala (Travancore) I, Tamil Nadu I

Karnataka (South Canara) I

Kerala (Travancore Hills) I

China R

Argentina $\mathbf{R}$

Oaxaca $\mathbf{R}$

Dominican Rep. I, Central America E,

Colombia E, Peru V

Peru R

Taiwan $\mathbf{R}$

Kerala (Peermade \& Cardomom Hills) I

Kerala (Koni and Ranni valleys) I

Taiwan (Heng-ch'un Pen., Lan Yu) R

Lord Howe I. R

Norfolk I. V

Cote d'Ivoire V, Liberia E

Cote d'Ivoire V, Liberia E, Uganda V/nt

Dominica I

Costa Rica R

Costa Rica R

Cote d'Ivoire V, Liberia E

Cote d'Ivoire V, Liberia E, Uganda V/nt

Benin V, Cote d'Ivoire V

Cote d'Ivoire V, Liberia E

Benin V

Cote d'Ivoire V, Liberia E

Australia E

Guatemala E, Colombia I, Peru E

Dominican Rep. I

Philippines V

China V

Costa Rica R

Guatemala R

Dominican Rep. I

Costa Rica E

Cuba (Camaguey, Las Tunas, Holguin) I

Peru R

Puerto Rico I

Cote d'Ivoire $\mathbf{R}$

Mauritius E, Reunion Ex

Zimbabwe R

Ghana V

Rodrigues ( 3 populations) $\mathrm{E}$

Mauritius R, Reunion E

Mauritius V

Mauritius I

American Samoa $\mathbf{R}$ 


\section{STERCULIACEAE}

Astyria rosea

Ayenia cajalbanensis

Ayenia limitaris

Basiloxylon excelsum

Buettneria astrotricha

Byttneria ivorensis

Byttneria scopiura

Cola attiensis

Cola crispiflora

Cola duparquetiana

Cola letestui

Cola lourougnonis

Cola octoloboides

Cola umbratilis

Commersoniatatei

Dombeya acutangula

Dombeya autumnalis

Dombeya delislei

Dombeya elegans

var. virescens

Dombeya ferruginea ssp.

ferruginea

Dombeya ferruginea ssp.

borbonica

Dombeya lastii

Dombeya leachii

Dombeya mauritiana

Dombeya populnea

Dombeya punctata

Dombeya rodriguesiana

Dombeya rotundifolia

var. velutina

Dombeya umbellata

Dombeya blattiolens

Eriolaena lushingtonii

Firmiana hainanensis

Firmiana major

Fremontodendron decumbens

Fremontodendron mexicanum

Guichenotia apetala

Heritiera fomes

Heritiera littoralis

Heritiera longipetiolata

Heritiera parvifolia

Hermannia helicoidea

Hermannia hispidula

Hermannia torrei

Lasiopetalum bracteatum

Lasiopetalum cardiophyllum

Lasiopetalum dielsii
Mauritius Ex

Cuba (Pinar del Rio) I

Texas I

Costa Rica E

Peru R

Cote d'Ivoire $\mathbf{R}$

Cuba (PR; SC; Gu) I

Cote d'Ivoire E/R

Gabon I

Gabon I

Gabon R

Cote d'Ivoire E/R

Kenya E

Ghana V

S. Australia R

Mauritius V, Reunion I, Rodrigues

(probably about 20 plants) E

Transvaal $\mathbf{R}$

Reunion $\mathrm{V}$

Reunion V

Ex

I

I

E

$\mathbf{R}$

I

$\mathrm{E} / \mathrm{R}$

I

I

R

E/R

E

V

R

I

$\mathbf{R}$

V

$\mathrm{V}$

Mauritius I I

Reunion I I

Mozambique $R / n t \quad R / n t$

Mozambique R/nt R/nt

Mauritius E

Mauritius Ex, Reunion E

Reunion $\mathrm{R}$

Rodrigues Ex/E

Namibia $\mathbf{R}$

E

$\mathrm{E}$

R

$\mathrm{Ex} / \mathrm{E}$

R

Reunion V

Reunion V

Andhra Pradesh (Kurnool Hills) I

China E

China $\mathbf{R}$

California I

California I

W. Australia V

Burma V

Burma V

Guam E, North Marianas (Rota; Saipan) E

China V

Cape Prov. $\mathbf{R}$

Cape Prov, I

Mozambique I

W. Australia E

W. Australia V

W. Australia R
V

V

I

E

R

I

I

V

-

-

$\overline{\mathrm{V}}$

R

I

I

E

V

R 
Lasiopetalum glabratum

Lasiopetalum

longistamineum

Lasiopetalum maxwellii

Lasiopetalum membranaceum

Lasiopetalum micranthum

Lasiopetalum old fieldii

Lasiopetalum rotundifolium

Lasiopetalum tepperi

Mansonia altissima

var. altissima

Mansonia gagei

Melhania denhami

Melhania futteyporensis

Melhania magnifolia

Melochia manducata

Nephropetalum pringlei

Nesogordonia papaverifera

Pavonia arabica

var. glutinosa

Pterospermum kingtungense

Pterospermum menglunense

Pterospermum reticulatum

Pterospermum yunnanense

Pterygota amazonica

Reevesia formosana

Reevesia rotundifolia

Ruizia cordata

Rulingia hermannifolia

Rulingia procumbens

Rulingia prostrata

Sterculia alexandri

Sterculia populnifolia

Sterculia zeylanica

Theobroma cirmolinae

Thomasia discolor

Thomasia gardneri

Thomasia glutinosa

Thomasia montana

Thomasia solanacea

Triplochiton scleroxylon

Trochetia blackburniana

Trochetia boutoniana

Trochetia granulata

Trochetia parviflora

Trochetia triflora

Trochetia uniflora

Trochetiopsis erythroxylon

Trochetiopsis melanoxylon

Ungeria floribunda

Waltheria nipensis

Waltheria pyrolaefolia
W. Australia V

N.S.W. V

W. Australia R

W. Australia R

Tasmania $\mathrm{V}$

W. Australia V

W. Australia E

S. Australia E

Benin (Ketou) I

Burma E

Egypt R, Sudan (Gebel Elba) $R$

Rajasthan (western) I

Rajasthan (western) I

Cuba (Pinar del Rio) E

Texas I

Benin V, Sierra Leone R

Rajasthan (Jaiselmer; Barmer; Jodhpur) I

China E

China $\mathbf{R}$

Kerala (Travancore Hills) I

China R

Peru R

Taiwan (south) $R$

China E

Reunion E

N.S.W. R

N.S.W. V

Australia V

Cape Prov. $R$

India (Deccan Hills, E. Ghats) I

Sri Lanka I

Colombia I

W. Australia R

W. Australia V

W. Australia V

W. Australia E

W. Australia R

Benin V

Mauritius R

Mauritius E

Reunion R

Mauritius Ex

Mauritius R

Mauritius E

St Helena E

St Helena E

Norfolk I. I

Cuba (Holguin) I

Hawaii Ex
V

V

R

R

V

V

E

E

-

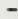

$-$

E

R

I

R

R

R

E

E

R

V

V

R

I

R

V

V

E

R

-

R

E

R

Ex

R

E

E

E

I

I

Ex 


\section{REFERENCES}

Anon. (1984a). A timber marketing project for member countries of the African Timber Organisation. A study presented by Tecsult International LTEE in collaboration with Groupe Poulin, Theriault LTEE.

Anon. (1984b). Tropical Hardwood Handbook. Commodity studies and Projections Division. Economic Analysis \& Projections Department.

ATIBT (1987). Tropical Timber Atlas, Volume 1: Africa. ATIBT, France.

Boelcke, C. and Croze, H. (1986). Tropical forest extent, changes, wood production, exports and imports. Unpublished m.s. GEMS/PAC, UNEP

Browder, J.O. (1986). Logging the Rainforest: A political economy of timber extraction and unequal exchange in the Brazilian Amazon.

Bruenig, E.F. (1985). Deforestation and its ecological implications for the rain forests in South East Asia. In: Davidson, J., Pong T.Y. and Bijleveld, M. (Eds). The Future of Tropical Rain Forests in South East Asia. Commission on Ecology Papers No. 10. IUCN, Gland, Switzerland.

Bull, J.W. (1985). Hardwood timber importing in the United Kingdom, 1852-1984. Journal of the Institute of Wood Science 10(4) 58: 154-159.

Centeno, J.C. (1985). La America Latina en el Comercio Internacional de la Madera Tropical. Instituto Forestal Latinoamericano, Merida, Venezuela.

CTFT (1987). Lesser known species. Unpublished pre-project report prepared for ITTO.

Davidson, J. (1985). Plantation forestry in relation to tropical moist forests in South East Asia. In: Davidson, J., Pong, T.Y. and Bijleveld, M. (Eds). The Future of Tropical Rain Forests in South East Asia. Commission on Ecology Papers No. 10. IUCN, Gland, Switzerland.

Durst, P.B., Ingram C.D. and Laarman, J.G. (1985). Statistics on forest products trade: are they believable? In: Schreuder, G.F. (Ed.). World Trade in Forest Products 2. University of Washington Press, Seattle and London.

Erfurth, T. and Rusche, H. (1976a). The Marketing of Tropical Wood, A: Wood species from African tropical moist forests. FAO, Rome.

Erfurth, T. and Rusche, H. (1976b). The Marketing of Tropical Wood, B: Wood species from South American tropical moist forests. FAO, Rome.

FAO (1982). Classification and Definitions of Forest Products. FAO Forestry Paper 32. FAO, Rome.

FAO (1985). Tropical Forestry Action Plan. FAO, Rome.

FAO Forestry Division (1986). Databook on Endangered Tree and Shrub Species and Provenances. FAO Forestry Paper 77. FAO, Rome.

Freezaillah, B.C.Y. (1984). Lesser-known tropical wood species: how bright is their future? Unasylva 36(3): 2-16.

Giordano, G. (1987). Pilot study of markets of high-value tropical timber products in Italy. Unpublished pre-project report prepared for ITTO.

Government of Indonesia and IIED (1985). A Review of Poicies Affecting the Sustainable Development of Forest Lands in Indonesia. IIED.

Guppy, N. (1983). The case for an organisation of timber exporting countries (OTEC). In: Sutton, Whitmore and Chadwick (Eds). Tropical Rainforest: Ecology and management. British Ecological Society Special Publications Series 2. Blackwell Scientific Publications, Oxford.

Guppy, N. (1984). Tropical deforestation: a global view. Foreign Affairs 62(4): 928-965.

de Guzman, E.D. (1975). Conservation of vanishing timber species of the Philippines. In: Williams, J. Lamouruk, C.H. and Wulijarni-Soetjipto, N. (Eds). South-East Asian Plant Genetic Resources. Proceedings of a symposium on South-East Asian plant genetic resources held at Bogor, Indonesia, March 1975. IBPGR, Bogor.

de Guzman, E.D. Umali, R.M. and Sotalbo, E.D. (1986). Guide to Philippine Flora and Fauna, Vol. 3: Dipterocarps. Non-Dipterocarps. Natural Resources Management Center, Ministry of Natural Resources and University of the Philippines.

Hansom, O.P. (1985). The Tropical Closed Forest. Research Report 6/85 TRADA, High Wycombe.

Hedegart, T. (1976). Breeding systems, variation and genetic improvement of teak (Tectona grandis L.f.). In: Burley, J. and Styles, B.T. (Eds). Tropical Trees: Variation, breeding and conservation. Linn. Soc. Symp. Ser. No. 2. Academic Press. 
Holliman, J. et al (1987). Japan's trade in tropical timber with South East Asia. In: Forest Resources Crisis in the Third World. Proceedings of a conference on forest resources crisis in the Third World, September 1986. Sahabat Alam Malaysia.

Hpay, T. (1986). The International Tropical Timber Agreement: Its prospects for tropical timber trade, development, forest management and conservation. IUCN/IIED Tropical Forest Policy Paper No. 3.

Kalafatis, S. (1982). Lesser known species survey. Timber Trades Journal and Wood Processing, Supplement, August 30-31.

Knees, S.G. and Gardner, M.F. (1983). Mahoganies: Candidates for the Red Data Book. Oryx 17(2): 88-92.

Leakey, R.R.B., Last, F.T. and Cossalter, C. (1984). West African Regional Hardwood Programme. Report of workshop meeting in Abidjan, Ivory Coast, October 1985, for UNEP and UNESCO.

Lucas, G.W. and Synge, H.A.S. (1978). The IUCN Plant Red Data Book. IUCN, Gland, Switzerland and Cambridge, UK.

McNeil, D.L. (1981). Tropical forest industries: a transnational corporation view. Commonwealth Forestry Review 60(2): 105-112.

Murthy, S.G. (1985). Sandalwood: case study of a resource decline. The Garden Jan/Feb: 16-19.

Myers, N. (1980). Role of timber trade in conversion of tropical moist forests. In: Myers, N. Conversion of Tropical Moist Forests. National Academy of Sciences, Washington DC.

National Academy of Sciences (1979). Tropical Legumes: Resources for the future. National Academy of Sciences, Washington DC.

Nectoux, F. (1985). Timber! An Investigation of the UK Tropical Timber Industry. Friends of the Earth, London.

Nectoux, F. and Dudley, N. (1987). A Hard Wood Story: Europe's involvement in the tropical timber trade. Friends of the Earth, London.

Odera, J.A. (1984). Forestry research for development of natural forests and indigenous species in Kenya. In: Endangered Resources for Development. Proceedings of a Workshop on status and options for management of plant communities in Kenya. National Environment and Human Settlements Secretariat, Nairobi.

Oldeman, R.A.A. (Ed.) (1982). Tropical Hardwood Utilisation: Practice prospects. Nijhoff, The Hague.

Overbeek, A. (1982). Example of an institutional framework in an importing country: The Netherlands. In: Oldeman, R.A.A. (Ed.). Tropical Hardwood Utilisation: Practice and prospects. Nijhoff, The Hague.

Piearce, G.D. (1986). How to save the Zambezi teak forests. Unasylva 152 Vol. 38(2): 29-36.

Roche, L. and Dourojeanni, M.J. (1984). A Guide to in situ Conservation of Genetic Resources of Tropical Woody Species. FAO, Rome.

Roche, L. and Hamann, O. (1985). Conservation of Endangered Tree Species. Paper for IX World Forestry Congress, Mexico City.

Schmidt, R.C. (in press). Current Programmes of Tropical Rain Forest Management. Proceedings of International Workshop on rain forest regeneration and management, 24-28 November 1986. Guri, Venezuela.

Shiva, V. (1987). Forestry Crisis and Forestry Myths. A Critical Review of Tropical Forests: A call for action. World Rainforest Movement, Malaysia.

Thang, H.C. (1987). National Report: Malaysia. In: Proceedings of ad hoc FAO/ECE/FINNIDA meeting of experts on forest resource assessment. Kotka, Finland, 26-30 October 1987. Finnida, Helsinki.

Towler, R.W. (1975). The possibilities of increased consumption of the lesser-known tropical hardwood species. Commonwealth Forestry Review 54 (3/4): 243-249.

UNCTAD (1981). Report of the Intergovernmental Group of Experts on Improvement of Market Intelligence on Tropical Timber. UNCTAD Trade and Development Board.

Von Meijenfeldt, C.F.W.M. (1985). The use of and alternatives for tropical hardwood in the Netherlands. Netherlands Journal of Agricultural Science 33: 115-123.

Wassink, J.T. and Wiselius, S.I. (1979). Aspects of the Marketing of Tropical Timber: A practical guide. Bull. 305, Dept. of Agricultural Research, Koninklijk Instituut voor de Tropen, Amsterdam.

WRI (1985). Tropical Forests: A call for action. World Resources Institute. 
Correspondence and personal communications cited

Erfurth, T. Senior Forestry Officer, Forestry Department, FAO, Rome (now retired).

Johns, A.D. Sub-Department of Veterinary Anatomy, University of Cambridge.

Kaarsegard, O.V. Market News Service Projects, ITC, Geneva.

Palmberg, C. Forest Resources Development Branch, Forestry Department, FAO, Rome.

Pleydell, G. Market Development and Information Services - Forest Industries, Woldingham, Surrey. 



1. The Gola Forest Reserves, Sierra Leone Wildlife conservation and forest management
A.G. DAVIES

2. Transmigration and the Environment in Indonesia The past, present and future ANTHONY J. WHITTEN, HERMAN HAERUMAN, HADI S. ALIKODRA and MACHMUD THOHARI

3. Conservation Planning in Indonesia's Transmigration Programme Case studies from Kalimantan JOHN DAVIDSON

4. The Management of Tropical Moist Forest Lands Ecological Guidelines DUNCAN POORE and JEFFREY SAYER

5. Buffer Zone Management in Tropical Moist Forests Case studies and guidelines SARA OLDFIELD

6. L'Equilibre des Ecosystèmes forestiers à Madagascar Actes d'un séminaire international LALA RAKOTOVAO, VERONIQUE BARRE et JEFFREY SAYER

7. Hunting and Wildlife Management in Sarawak JULIAN CALDECOTT

Series editors: Mark Collins and Jeffrey Sayer

Published by IUCN

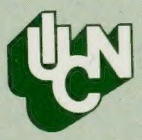

This book is part of

THE IUCN CONSERVATION LIBRARY

For a free copy of the complete catalogue please write to: Publications Unit, IUCN Conservation Monitoring Centre, 219c Huntingdon Road, Cambridge, CB3 ODL, UK 